\title{
Cell Senescence, Multiple Organelle Dysfunction and Atherosclerosis
}

\author{
Gisela Machado-Oliveira *, Cristiano Ramos, André R. A. Marques and Otília V. Vieira *(D) \\ CEDOC, NOVA Medical School, Faculdade de Ciências Médicas, Universidade NOVA de Lisboa, \\ 1169-056 Lisboa, Portugal; cristiano.ramos@nms.unl.pt (C.R.); andre.marques@nms.unl.pt (A.R.A.M.) \\ * Correspondence: gisela.oliveira@nms.unl.pt (G.M.-O.); otilia.vieira@nms.unl.pt (O.V.V.); \\ Tel.: +351-2-1880-3100 (G.M.-O. \& O.V.V.); Fax: +351-2-1880-3010 (G.M.-O. \& O.V.V.)
}

Received: 31 August 2020; Accepted: 20 September 2020; Published: 23 September 2020

\begin{abstract}
Atherosclerosis is an age-related disorder associated with long-term exposure to cardiovascular risk factors. The asymptomatic progression of atherosclerotic plaques leads to major cardiovascular diseases (CVD), including acute myocardial infarctions or cerebral ischemic strokes in some cases. Senescence, a biological process associated with progressive structural and functional deterioration of cells, tissues and organs, is intricately linked to age-related diseases. Cell senescence involves coordinated modifications in cellular compartments and has been demonstrated to contribute to different stages of atheroma development. Senescence-based therapeutic strategies are currently being pursued to treat and prevent CVD in humans in the near-future. In addition, distinct experimental settings allowed researchers to unravel potential approaches to regulate anti-apoptotic pathways, facilitate excessive senescent cell clearance and eventually reverse atherogenesis to improve cardiovascular function. However, a deeper knowledge is required to fully understand cellular senescence, to clarify senescence and atherogenesis intertwining, allowing researchers to establish more effective treatments and to reduce the cardiovascular disorders' burden. Here, we present an objective review of the key senescence-related alterations of the major intracellular organelles and analyze the role of relevant cell types for senescence and atherogenesis. In this context, we provide an updated analysis of therapeutic approaches, including clinically relevant experiments using senolytic drugs to counteract atherosclerosis.
\end{abstract}

Keywords: atherosclerosis; senescence; senescent organelles; cardiovascular diseases

\section{Introduction}

Atherosclerosis is a chronic inflammatory, progressive and age-linked condition that is associated with the development of major cardiovascular diseases (CVD), including ischemic heart and peripheral vascular disease as well as particular ischemic strokes [1]. Atherogenesis, the formation of atheromatous plaques in the arterial wall, is initiated by retention and extensive oxidative modifications of low-density lipoproteins (LDL) in the arterial intima, leading to endothelium activation and monocyte recruitment and migration across the endothelial barrier. Monocytes subsequently differentiate into a macrophage phenotype, accounting for phagocytosis and degradation of the excessive accumulation of oxidized LDL. The cellular metabolization pathways of macrophages eventually become overloaded, which inevitably lead to irreversible accumulation of lipids within the lysosomal compartment and disrupted lysosome function. As a consequence, macrophages transform into foam cells that are unable to contribute to additional lipid metabolization and initiate the secretion of pro-inflammatory factors that further aggravate the development of the atheromatous plaques. The accumulation of oxidized LDL to levels that overcome the metabolization capacity of macrophage and foam cell's lysosomes thus appears a very relevant cellular event to trigger atherogenesis [2-4]. 
Along with the cellular differentiation of macrophages occurring in the arterial intima, vascular smooth muscle cells (VSMC) from the tunica media also migrate into the sub-endothelial region. These cells become highly proliferative and tend to surround the evolving inflammatory process, forming a fibrous cap that stabilizes the plaque. Nevertheless, fibrous cap formation by VSMC also involves the secretion of extracellular matrix proteins, which facilitate plaque rupture $[5,6]$. Moreover, in more advanced atherosclerotic plaques, VSMCs can develop a foam cell-like phenotype, aggravating the lesion [7-9]. Notably, the structure of the atherosclerotic plaques is defective in the long term and continue to progress to mature atheromatous plaques containing a large necrotic core and a thin fibrous cap that over time becomes increasingly susceptible to rupture [10]. Depending on the size of the plaque and the capacity to enclose the inflammatory process, the rupture of the fibrous cap can lead to vessel thrombosis and the potentially deadly acute vascular diseases [10].

As an age-related disease, atherosclerosis is associated with a number of biological processes including cellular senescence [11]. Overtly, the multiple senescent cell types present in the vasculature were reported to ease various pathophysiological processes in atherosclerosis [12], with the senescenceassociated pro-inflammatory phenotype (SASP) gradually contributing to atherosclerotic plaque progression and destabilization $[13,14]$. In atherosclerotic lesions, cellular senescence is driven not only by the exhaustion of replicative potential that is normally associated with aging, but also by a variety of other cellular stressors such as oxidized LDL [stress-induced premature senescence (SIPS)] [15], processes that will be further detailed in the next section. The inter-related sequence of senescence-driving events governing atheroma progression are represented schematically for clarity (Figure 1). In this review, we present the existing evidence regarding the main senescence cellular alterations taking place during atheromatous plaque maturation, with particular focus on the role of specific organelles in the senescent processes associated with atherosclerosis development. Lastly, we discuss potential strategies to circumvent cellular senescence and highlight the improvements still required in the field in order to develop novel therapeutic approaches for cardiovascular disorders.

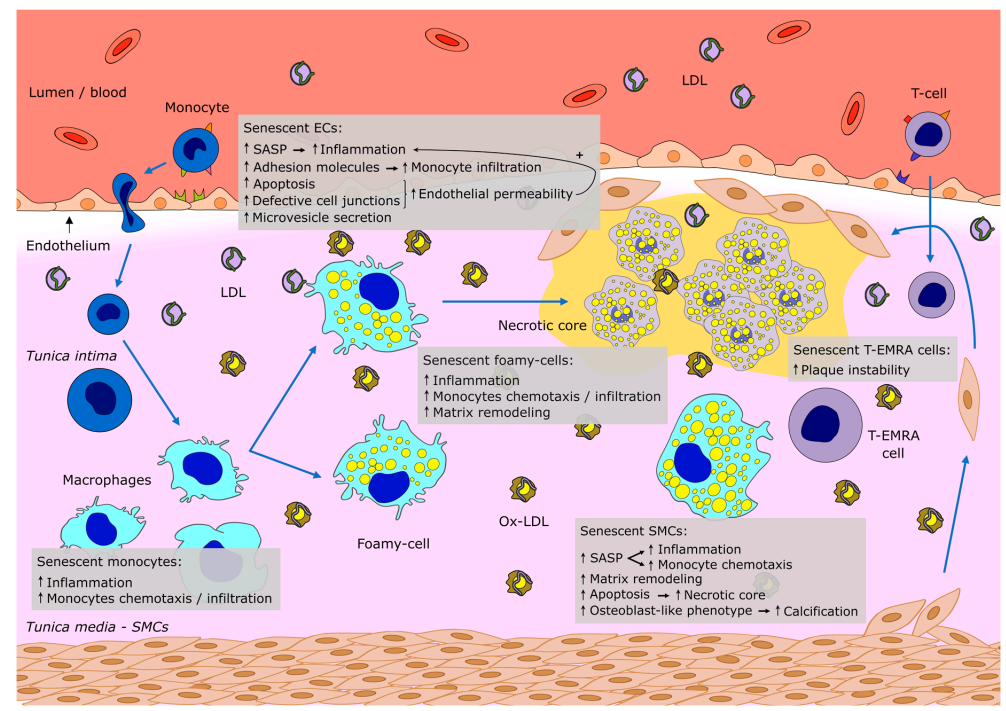

Figure 1. Schematic representation of an artery wall section showing the main events driven by senescent vascular cells, which contribute to the atheroma progression and consequently vascular disease development. The typical senescence-associated pro-inflammatory phenotype (SASP) fuels inflammation, monocyte chemotaxis and endothelial infiltration, eased by increased endothelial permeability. The accumulation of oxidized lipids in the vascular wall and consequent foam cell formation occur along with the recruitment of vascular SMCs from the media to form a fibrous cap, which progressively becomes destabilized. Senescent immune cells found at lesion sites contribute to plaque instability, acting synergistically with calcification events to increase the vessel vulnerability. ECs-endothelial cells, SMCs—smooth muscle cells, LDL-low density lipoprotein, SASP—senescent-associated secretory phenotype. 


\section{Cell Senescence Overview}

Cellular senescence is classically characterized by an irreversible cell cycle arrest that might be prompted by DNA damage, oxidative stress, nutrient deprivation, oncogenic insults or chemotherapeutic-induced toxicity. In addition, the irreversible cell cycle arrest in senescent cells is primarily imposed by an upregulation of the cell cycle inhibitors p16, p21 and p53 [16,17]. Senescence is associated with cellular alterations such as cytoplasm enlargement as well as irregular and flat morphology, distinctive features from those of proliferating cells. Likewise, functional modifications including increased resistance to apoptosis and development of the typical SASP, also take place during the process of replicative senescence, whilst maintaining metabolic activity. Particularly relevant, SASP is associated with the release of a number of factors including bioactive lipids, extracellular vesicles, proteins and nucleotides that mediate core pathophysiological events in senescence. More specifically, SASP is involved in the recruitment of immune cells, modification of the extracellular matrix and supports the maintenance of the cell-cycle arrest [17]. Indeed, the cellular secretions of the SASP act as paracrine and autocrine mediators that promote inflammation, aberrant communication between surrounding cells and ultimately lead to defective tissue remodeling [18-20]. SASP elements were reported to stimulate the immune system for senescent cell clearance, a protective process that eventually becomes inefficient with aging, resulting in intensified inflammatory responses and chronic inflammatory disorders [21,22]. As such, senescent cells tend to chronically accumulate in multiple aged tissues [18], indicating that senescence may contribute to regulating the non-pathological age-associated events. In addition, different studies have pointed to cellular senescence as being involved in a number of age-related diseases, such as atherosclerosis, cancer, hepatic steatosis, Alzheimer's disease, fibrotic pulmonary disease and osteoarthritis [23-28], which indicates that cell senescence may be entailed in driving these diseases. Specifically, senescent cells have been found to accumulate in sites of atherosclerosis ex vivo in human samples [29,30], again suggesting the involvement of cell senescence in sculpting this disease. Studies conducted in LDL receptor deficient-mice have also shown that the removal of $\mathrm{p} 16^{\mathrm{INK} 4 \mathrm{a}}$-positive senescent cells from atherosclerotic plaques contributed to repressing the typical pathological modifications [13], and can account for the suppression of the aging phenotype in different organs, including in the murine heart [23]. Nevertheless, cell senescence is also characterized by beneficial physiological functions, including its participation in cancer protection, as it is a way to avoid transmission of genetic and organelle damage through cell proliferation, and its role in the guidance of early embryonic development and in tissue repair [31].

In contrast to SASP, SIPS manifests upon exposure to exogenous cellular insult, such as oxidative stress. Both replicative senescence and SIPS prompt the same cell phenotype, and are regulated by some common signaling pathways, though the telomere length appears not to be altered in SIPS, thus conferring potential reversibility on this process [15]. Specifically, replicative senescence and SIPS can be mediated via the p53/p21 or p16 signaling pathways, depending on the type of cell and the species involved [32,33]. Telomere shortening activates either the p53/p21 or p16 pathways in humans, while only the p53/p21 pathway is induced in mice [34]. Still, it is generally established that telomere shortening and DNA damage lead to the induction of the p53/p21 pathway, while oxidative stress and general cellular stressors activate the p16 signaling pathway $[32,33,35]$. On the other hand, oncogene-induced senescence (OIS) implies cell proliferation arrest due to the activation of oncogenes such as Ras or pRB [27,36]. Importantly, additional studies have shown that senescence is not restricted to proliferating cells. Post-mitotic cardiomyocyte senescence was recently reported to occur independently of telomere shortening and damage [37]. In particular, senescent cardiomyocytes were shown to contribute to SASP, promoting cardiomyocyte hypertrophy in mice [37]. Senescent human cardiac progenitor cells were also reported to accumulate in failing hearts with advanced age, compromising heart regeneration due to SASP [38]. Importantly, amongst the different types of cardiac senescent cells, cardiomyocytes, as the main functional units of the heart, greatly contribute to cardiac senescence, compromising myocardial performance. Senescent cardiomyocytes were shown to exhibit functional decline, including reduced contractility, mitochondrial dysfunction and increased size. 
As a result of senescent cardiomyocytes accumulation with age, chronic inflammation is promoted, leading to cell death $[39,40]$. Interestingly, Meis1, a senescence-associated gene, was shown to contribute to the regulation of hematopoietic stem cell metabolism and oxidant stress response, via the transcriptional regulation of hypoxia-inducible factors [41]. More recent studies revealed that silencing senescence-mediated pathways through inhibition of Meis2 and Rb1 in adult rat cardiomyocytes leads to cardiomyocyte proliferation and cardiac repair upon myocardial infarction [42]. In addition, FoxO3 was recently reported to mediate cardiac protection from oxidative stress, counteracting cardiac dysfunction, apoptosis and senescence in mice [43]. Additional studies have revealed that melatonin inhibited cardiac progenitor cell senescence in response to oxidative stress, via H19/miR-675 pathway [44]. Moreover, the human amniotic fluid stem cell secretome was shown to antagonize senescence of mouse cardiomyocytes and human cardiac progenitor cells, via the modulation of NF-kB-mediated transcription [45]. Other studies also focus on the description of mechanisms fueling senescence in post-mitotic cells and its contribution to aging and tissue degeneration [46,47], but further research is needed to fully clarify the post-mitotic cell senescence process.

In addition, it has been reported that all senescent cells share a common secretory profile and that each particular senescent cell type also tends to express more specific secretory factors (see Table 1 to compare differential secretome profiles between cell types) [48]. Accordingly, senescent human fibroblasts and epithelial cells were shown to express different SASPs in culture. Human epithelial tumor cells also acquire the SASP and express specific secretions (in vivo) after being exposed to DNA-damaging chemotherapy. Moreover, the malignant epithelial-mesenchyme transition (EMT), which confers invasive and metastatic properties on epithelial cells, was demonstrated to be stimulated by senescent cells, via the SASP interleukins IL-6 and IL-8. Remarkably, both the oncogenic RAS and the loss-of-function of the tumor suppressor p53 caused amplification of the SASP, which suggests that senescent cells may provide a tissue microenvironment that supports different stages of tumor progression [48]. Taken together, the conserved secretory profile and the more intrinsic secretory factors related to the particular cell genotype and tissue of origin suggest that the SASP is not a steady phenotype and continues to intervene actively in numerous pathophysiological processes.

Table 1. Major SASP components in different senescent cell types.

\begin{tabular}{|c|c|}
\hline Cell Type & SASP Components \\
\hline \multirow{5}{*}{ Human fibroblasts } & Interleukins: IL-1b, IL-6, IL-7, IL-8, IL-11, IL-13, IL-15 \\
\hline & $\begin{array}{l}\text { Chemokines and cytokines: GRO-a, GRO-b, GRO-g, MCP-1, MCP-2, MCP-4, MIP-1a, MIP-3a, } \\
\text { HCC-4, Eotaxin-3, MIF, GM-CSF, OSM, Leptin }\end{array}$ \\
\hline & $\begin{array}{c}\text { Growth factors and regulators: bFGF, FGF-7, SCF, PIGF, HGF, IGFBP-1, IGFBP-2, IGFBP-4, } \\
\text { IGFBP-6, Angiogenin }\end{array}$ \\
\hline & Proteases and regulators: TIMP-2 \\
\hline & $\begin{array}{c}\text { Receptors and ligands: ICAM-1, ICAM-3, sTNF RI, sTNF RII, TRAIL-R3, uPAR, Axl, OPG, } \\
\text { Fas/TNFRSF6, sgp130 }\end{array}$ \\
\hline \multirow{5}{*}{$\begin{array}{l}\text { Human epithelial } \\
\text { cells }\end{array}$} & Interleukins: IL-1a, IL-1b, IL-2R-a, IL-6, IL-8 \\
\hline & $\begin{array}{l}\text { Chemokines and cytokines: GRO-a, GRO-b, GRO-g, MCP-1, MCP-4, MIP-1a, MIP-3a, HCC-4, } \\
\text { CTACK, I-TAC, GM-CSF, GCP-2, ENA-78, MIF }\end{array}$ \\
\hline & $\begin{array}{c}\text { Growth factors and regulators: bFGF, PIGF, VEGF, PDGF-BB, IGFBP-2, IGFBP-6, Amphiregulin, } \\
\text { Thrombopoietin, Angiogenin }\end{array}$ \\
\hline & Proteases and regulators: TIMP-1, TIMP-2 \\
\hline & Receptors and ligands: ICAM-1, IL-6R, uPAR, EGF-R, sTNF RI, sTNF RII, GITR, OPG, sgp130 \\
\hline \multirow{3}{*}{$\begin{array}{l}\text { Human epithelial } \\
\text { cancer cell lines }\end{array}$} & Interleukins: IL-1b, IL-6, IL-8 \\
\hline & Chemokines and cytokines: GRO-a, GM-CSF \\
\hline & Growth factors and regulators: IGFBP-2 \\
\hline
\end{tabular}




\section{Endothelial, Smooth Muscle and Immune Cells: Major Senescence Traits Implicated in Vascular Disease}

Studies including post-mortem histological analysis have provided clinical data demonstrating considerable accumulation of different types of senescent cells in atherosclerotic arteries in comparison to aged healthy vessels [14]. Endothelial cells (ECs), which form the endothelium, are located on the arterial intima and maintain vascular homeostasis, being entailed in several biological functions, such as blood pressure regulation, coagulation, angiogenesis and inflammatory response [49]. Importantly, ECs are continuously subject to hemodynamic forces, being capable of remodeling their cytoskeletal structure and evoke adaptive signaling pathways to minimize intracellular stress and maintain vascular homeostasis. Nonetheless, pathological mechanical forces or excessive inflammation leads to perturbed EC responses, decreasing nitric oxide synthesis, increasing adhesion molecules expression and oxidative stress, resulting in EC dysfunction [50], which frequently leads to CVD. However, depending on a number of predisposing factors such as advanced age, elevated salt intake, hypercholesterolemia, hyperglycaemia and hypertension, the mechanisms underlying the endothelial dysfunction can be markedly different [49]. In particular, age is a critical cardiovascular risk factor contributing to the development of atherosclerosis [51], with senescent ECs being frequently found in atherosclerotic plaques of elderly patients [52-54]. In this instance, EC senescence has been proposed as a pathophysiological contributor to developing vascular disease [27]. Further confirming this concept, active proatherogenic mechanisms are present in senescent cells of aging vessels and senescent ECs have been shown to present lower NO generation and increased expression of the adhesion molecules VCAM1 and ICAM1, which bind monocytes prompting endothelium infiltration [55]. In vitro studies have also revealed that senescent ECs are more prone to undergoing apoptosis and show compromised formation of tight junctions, which can enhance the retention of oxidized LDL in the arterial intima and contribute to atherogenesis $[56,57]$. In agreement with this, monocytes have been reported to have higher binding affinity to senescent ECs, shown in X-ray-induced or replication-induced senescent ECs [58], suggesting that ionizing radiation can cause CVD. Moreover, at the vessels' bifurcation sites, where blood flow is disturbed, ECs exhibit shorter telomeres, indicating senescence exacerbation. In addition, senescent ECs induced by disturbed flow display reduced migration and altered expression of inflammatory factors, which may be due to the activation of p53/p21 signaling [59]. Consistently, protection against oxidative stress and age-associated endothelial senescence was reported to be achieved via the inhibition of NF-kB signaling [60], a potent promoter of p53-mediated SASP in human and rodent cells [61-63]. Furthermore, ECs produce extracellular vesicles, the endothelial microvesicles, which act as extracellular mediators that contribute to maintaining the vessel homeostasis [64], and whose functional disruption has been related with endothelial senescence. Senescent cells can develop the SASP and increase the secretion of both soluble factors and extracellular vesicles that act as conveyors of senescence signals [65]. Indeed, various studies have shown that extracellular vesicle secretion increases during senescence [66-68]. These facts point to the microvesicles as being part of the SASP, potentially constituting a mechanism to allow the release of insoluble proteins and the activation of specific signaling pathways in the target cells [69], possibly playing a role in the atherosclerotic plaque developmental process. In addition, microvesicles from elderly individuals' plasma or senescent ECs were reported to stimulate the calcification of human aortic SMCs. Not only the microvesicles in the plasma rise with aging, but also the senescent EC-secreted microvesicles contain higher quantities of calcium and calcium-binding proteins, known to participate in vascular calcification, indicating that microvesicles could be used as markers of vascular calcification in atherosclerotic plaques [67].

The arterial media is formed in part by VSMCs that synthesize the extracellular matrix and are responsible for the vessel contraction [70]. A number of studies have provided evidence for the occurrence of VSMC senescence in atherosclerosis. VSMCs derived from human atherosclerotic plaques exhibit a lower level of proliferation [71], higher p16 and p21 expression levels and a larger and flattened morphology in comparison to cells from healthy arterial media [72]. Replicative VSMC senescence, reported to occur in human atherosclerosis, was associated with decreased telomere length 
in the more advanced and severe atherosclerotic processes, possibly due to higher rates of VSMC proliferation during early lesion development. Still, oxidative stress also causes telomere shortening and VSMC senescence, contributing to the acceleration of the atherogenic process [29]. In particular, pro-oxidants have been postulated to trigger SIPS in human VSMCs [73], whereas chronic oxidative stress accelerates replicative senescence [29]. Additionally, there are reports of DNA damage-induced VSMC senescence in atherosclerotic mice [74]. Not only a reduction in telomere length, but also the loss of telomere binding factors and modifications in the telomere structure may trigger VSMC senescence in atherosclerosis [75]. Apart from the changes in senescent VSMC proliferative potential, which can prompt atherosclerotic plaque instability due to the reduction in VSMCs in the fibrous cap, other studies indicated that VSMC senescence promotes plaque destabilization via stimulation of inflammation. Senescent human VSMCs release SASP mediators and display reduced expression of anti-inflammatory factors. SASP mediators' secretion induces chemotaxis of monocytes and stimulates neighbor non-senescent VSMCs and ECs to secrete cytokines and express adhesion molecules, enhancing disease progression. Moreover, senescent human VSMCs produce lower amounts of collagen than normal VSMCs, which can increase plaque vulnerability [76]. In addition, VSMCs may additionally assume an "osteoblast-like" phenotype, increasing their susceptibility to calcification, during replicative senescence events $[77,78]$, which is related with cardiovascular complications and possibly also contributing to plaque vulnerability [79]. Even though most available data focus on the role of senescent VSMCs in advanced atherosclerotic lesions, there are also reports demonstrating their potential involvement during early plaque development [80], emphasizing the importance of normal VSMC function in protecting the arteries against atherosclerosis. Autophagy, a cellular mechanism that allows removal of unnecessary or dysfunctional components, was shown to protect VSMCs from cell death and to suppress VSMC senescence, upon moderate activation [81-83]. Therefore, the imbalance amongst these pathways possibly fuels the development of unstable atherosclerotic plaques [84].

Immune system cells, particularly the senescent immune cells found in the vasculature wall, also contribute to the development of atheroma. Indeed, different studies have revealed that senescent leukocytes contribute to the progression of atherosclerotic plaques and senescent effector memory $\mathrm{T}$ (T-EMRA) cells were identified in unstable atherosclerotic plaques [85]. For instance, aged individuals presenting leukocytes with shortened telomeres were reported to have higher mortality, at least in part due to heart disease [86]. Most interestingly and potentially clinically relevant, leukocyte population analysis indicates that telomere shortening allows for the prediction of atherosclerosis and CVD $[87,88]$, and CD4+ as well as CD8+ T-EMRA cells are considered predictors of cardiovascular-related mortality in older individuals [89]. In addition, patients with advanced atherosclerosis have been shown to display monocytes that tend to produce elevated levels of ROS and pro-inflammatory cytokines $[13,90]$. Moreover, these pro-inflammatory phenotypic alterations in macrophages were shown to be driven by cellular senescence [91]. Transgenic and pharmacological approaches also revealed that subendothelial senescent foam macrophages present in early lesions enhance tumor necrosis factor (TNF)- $\alpha$-mediated Vcam1 expression and the monocyte chemoattractant protein-1 (MCP-1) gradient, to maintain monocyte recruitment to the site of lesion [13].

\section{Cellular Organelles in Senescent Cells}

Senescent cells exhibit morphological and functional defects, which derive from intracellular alterations in their morphology, function, level of development and mass of their organelles. Independently of the specific intracellular organelle, senescence imposes common alterations including functional deficiencies, an increase in total organelle mass and abnormal intracellular signaling [92]. Classic biological senescence markers point to organelle defects, as detailed below. Briefly, dysfunctional lysosomes commonly exhibit increased senescence-associated $\beta$-galactosidase (SA- $\beta$-gal) activity, whereas defective oxidative phosphorylation in mitochondria results in increased reactive oxygen species (ROS) production. In addition, senescence-related alterations in the endoplasmic reticulum (ER) lead to the unfolded protein response (UPR), along with the DNA damage and the senescence-associated 
heterochromatin foci (SAHF) in the nucleus. Although it is still not completely elucidated how these intracellular alterations in morphology and function take place and which regulatory pathways induce multiple organelle dysfunction, they are likely related, either by consequence or predisposal, to the defects in cellular metabolism detected during senescence [93]. One leading hypothesis is that the increased organelle production by senescent cells may occur as a compensatory response for the defective organelle function caused by the oxidative stress. Still, the lately produced organelles potentially worsen senescence due to the continuous exposure to ROS [93].

In normally functioning cells, the proteome's integrity is maintained via a concerted regulation between autophagy, proteasome-dependent degradation and chaperone-mediated protein folding. These regulatory mechanisms also appear to be impaired during cellular senescence as protein damage and aggregates and abnormal protein synthesis are highly prominent [94]. In addition, macroautophagy, which controls the elimination of damaged organelles resulting from oxidative stress, is frequently not operating adequately, leading to further deregulation of organelle homeostasis $[95,96]$. Therefore, the increased organelle mass that characterizes senescent cells is likely to be related to mitochondrial dysfunction, anomalous anabolic activities and defective autophagy, which in turn result in additional oxidative stress and aggravated deregulation of organelle biogenesis.

\subsection{Mitochondria and the Lysosomal Compartment}

Amongst all cellular organelles, mitochondria and lysosomes show the most pronounced changes during cell senescence [97-99]. Mitochondria are the main source of cellular ATP [100], displaying fusion cycles to mix the contents of partially damaged organelles [101,102], and fission cycles to generate new mitochondria and enable the degradation of dysfunctional organelles by autophagy [103]. Mitochondrial DNA damage has been stated to be potentially involved in cellular senescence [104], and a number of studies revealed mitochondrial oxidative phosphorylation dysfunction's involvement in different senescence cellular models [105-111]. Dysfunctional mitochondria are thus a hallmark of cell senescence, which was reinforced by another study involving targeted depletion of mitochondria, also demonstrating that mitochondria contribute to regulate the SASP and to promote the cell-cycle arrest in senescent cells. In this context, ROS generation by mitochondria and the consequent DNA damage response were shown to contribute to develop the senescent phenotype, while the mechanism underlying the cell-cycle arrest is still not completely understood [112].

Phenotypic and morphological alterations in senescent mitochondria include organelle enlargement [113-115] and increased mitochondrial cell mass [115,116]. Although the mechanism and the regulatory pathways of the mitochondrial senescence are not completely clarified, it has been proposed that damaged enlarged mitochondria may accumulate throughout senescence because of complications during autophagic degradation [117,118]. In particular, mitochondrial fission activity is downregulated during cellular senescence [119], potentially decreasing mitochondrial autophagic turnover (mitophagy) [115], thus incrementing mitochondrial mass. Likewise, an inefficient synchronization between autophagy, mitochondria fission and fusion also appears to take place in senescent and aged cells, leading to the accumulation of damaged mitochondria [120]. In agreement with this, blocking mitochondrial fission triggers a senescence-like state, with the formation of elongated mitochondria and enhancing the generation of ROS [115,121]. Adding to the decrease in autophagic turnover, defective autophagic processes also result in compromised formation of autolysosomes and reduced digestion, leading once more to the pathological accumulation of dysfunctional mitochondria. Taken together, it appears clear that senescent cells may become unable to control the mitochondrial mass, leading to a progressive increase in the mass of defective mitochondria per cell [93], which can consequently give rise to premature senescence or even apoptosis [122]. Importantly, impaired mitophagy has been related with the development of age-associated cardiovascular pathologies. Accordingly, the mitochondrial enzyme monoamine oxidase-A (MAO-A) has been reported to drive SIPS in cardiac cells via mitophagy impairment and consequent mitochondrial dysfunction and chronic ROS generation [123]. 
Similar to that proposed for the other organelles, it has been hypothesized that the increase in mitochondrial mass occurs as a cellular compensatory mechanism for the functional mitochondria decay [124,125]. This is particularly relevant for the case of mitochondria that possess their own mitochondrial DNA and retrograde signaling pathways to the nucleus. Indeed, cellular compensatory mechanisms for mitochondrial proliferation and potentiation of oxidative capacity are well known and frequently reflected in disorders associated with mitochondrial damage, like the CVD [126-128]. Amongst the mitochondrial retrograde signaling events, transcriptional reprogramming and modulation of different cellular functions are entailed in changing the cell fate to proliferation, senescence or death [129-133]. ROS, one of the mitochondrial retrograde signaling messengers, is known to damage DNA, lipids and proteins, leading to the activation of damage responses. Nevertheless, mitochondria and the mitochondrial DNA are particularly vulnerable to damage, as the electron transfer chain is the main site for ROS production. This, combined with the high number of mitochondria present in cells, makes these organelles remarkable in disseminating oxidative stress and prompting senescent phenotypes [134-137]. Oxidative stress causes DNA damage by oxidizing nucleotide bases and inducing single- (SSB) and double-strand breaks (DSB). DSB stimulate a DNA damage response and the expression of the cell-cycle inhibitors p53 and p21, which mediate senescence, and result in the staining of the SAHF. DSB-mediated DNA damage response, also called telomere-independent premature senescence, in contrast with the SSB, to which the telomeres are susceptible due to the enrichment in guanine triplets, indicating that the mitochondria-induced oxidative stress may contribute to define the telomere status [138,139].

Remarkably, senescent cells were reported to extrude fragments of chromatin from the nucleus into the cytoplasm [140]. This cytoplasmic chromatin fragments (CCFs) were stated to induce the SASP during cell senescence [141-143]. In this context, a recent study revealed that the formation of CCFs and thus the activation of the SASP are initially triggered by mitochondria-nuclear retrograde signaling pathways, possibly prompted by increased ROS production in dysfunctional mitochondria [144].

Mitochondrial defective function and related ROS generation can also cause lipid oxidation and lipid deposits [25,112], as well as lipofuscin accumulation [145]. Although the accumulation of lipids is known to occur in senescent cells, the characterization of such lipids, the alterations of lipid metabolism and their role in senescence and atherosclerosis are still very poorly elucidated. Despite the various methods that can be used to detect the lipid profile in cells, senescence-associated lipidomics is highly variable. A significant variation of lipid metabolites between replicative senescence and OIS is an example of the great differences in lipid metabolite composition in senescent cells. In addition, these differences in the metabolic profile appear to be partly explained by the initial trigger and the type of cell involved [146]. Considering the central lipid deposition events driving the formation of atheromas and the associated involvement of cell senescence, it is clear that further clarification of the lipid metabolism in senescent cells is imperative to better elucidate atherogenesis. Additionally, although a great deal of investigation is clearly required, the high variability in the composition of intracellular lipids between adult cells and cells enduring pathological processes opens the possibility to unravel the lipid profile of different organelles or a bulk lipid profile that can be used as a biomarker of senescence.

Lysosomes are involved in several cellular functions, being considered the main catabolic organelles [147], containing hydrolytic enzymes and highly acidic conditions to degrade a multiplicity of substrates [148]. A number of in vitro and in vivo studies revealed an increased lysosomal mass in senescent somatic cells and in aged post-mitotic cells [149-153]. The observed increase in the lysosomal mass was reported to be mostly due to an increase in the number of lysosomes containing an indigestible cargo such as lipofuscin, occasionally called residual or dense bodies [154]. Remarkably, lipofuscin was shown to induce the expression of $\mathrm{Bcl}-2$, which confers resistance to apoptosis, leading to the hypothesis that the accumulation of lipofuscin can also be involved in the regulation of cellular senescence [155]. In contrast, lysosomes accumulate oxidized LDL-derived lipids in the macrophages and VSMCs at atheromatous sites $[3,4,7]$. In addition, several research lines indicate that lysosome 
biogenesis increases during cellular senescence [121,156-160], which is usually supported by elevated SA- $\beta$-gal activity, a marker of increased lysosomal number or activity [161]. The increase in the lysosomal mass observed during cellular senescence is thus associated with progressive structural alterations and accompanied by changes in lysosomal activity. Intrinsically related with this is the modification of the lysosomal $\mathrm{pH}$ that alters the activity of the majority of the lysosomal enzymes [162] and compromises the substrates of autophagic degradation as well as the endocytic cargo in senescent lysosomes [163-165]. Most interestingly, it has been recently shown that lysosomal oxidation of aggregated LDL alters the lysosomal $\mathrm{pH}$, inducing cellular senescence and increasing secretion of pro-inflammatory cytokines in human macrophages [166]. These findings reinforce once more the active contribution of senescent lysosomes and the process of cellular senescence for atherogenesis. Other relevant functions of lysosomes during cell senescence include the clearance of the CCFs and the anabolic metabolization of chromatin. Indeed, it has been reported that CCFs extruded from the nucleus of senescent cells were targeted to be processed by the lysosomal/autophagy machinery [140]. According to the data gathered, other authors have demonstrated that senescent lysosomes exhibit reduced capacity to sense and respond to internal and external stimuli, which reflects their central role in the integration of multiple signals, governing cellular senescence and aging [167]. In this context, it is important to stress the involvement of the lysosomal/autophagy machinery in regulating the inflammasome, a protein complex that is involved in the secretion of some inflammatory cytokines. Specifically, defective autophagic clearance of inflammasomes has been shown to be implicated in the development of cardiometabolic disease [168], further reinforcing the consequences of the lysosomal/autophagy system being compromised.

Most interestingly, senescent cells have been shown to activate the mechanistic target of rapamycin complex 1 (mTORC1), a lysosomal serine-threonine kinase that regulates autophagy, protein synthesis, metabolism, cell growth and survival [169-172], these processes being specifically inhibited by rapamycin [173]. The mTORC1 activation in senescent cells may arise from defects in amino acid and growth factor sensing, partly due to the depolarization of senescent cell plasma membrane, compromising the inhibition of growth factor signaling [174]. mTORC1 induction in senescent cells may also contribute to developing the SASP, as mTORC1 inhibitors seem to reduce inflammation instigated by senescent cells and consequently the SASP [175]. Agreeing data were provided, indicating that these mTORC1 inhibitors operate via different mechanisms to inhibit the SASP, contributing to the up-regulation of DNA repair proteins and associated post-transcriptional modifications [174,176]. Importantly, inhibition of the mTOR pathway has already been reported to result not only in anti-senescence but also in anti-atherosclerotic effects [177-179].

Apart from the well-established crosstalk between mitochondria and the nucleus, several lines of evidence reveal the importance of a lysosomal-mitochondria axis in the regulation of cellular senescence. Coupling mitophagy and autophagy induction has been suggested to underlie the significance of the lysosomal-mitochondria axis in the control of cell senescence [97]. Accordingly, re-establishment of the lysosomal-mitochondria axis was reported to cause the reversion of senescent to juvenile phenotypes [98]. Indeed, studies in C. elegans have also shown that mitochondrial functional recovery is triggered by lysosomal acidification, reflecting the implication of the lysosomal-mitochondria axis in attenuating senescence [99]. As such, amongst the complex organelle interplay in cells, the lysosomal-mitochondria axis appears to be emphasized due to its role in regulating cell senescence.

\subsection{Peroxisomes, Cytoskeleton and Nuclei}

Peroxisomes are highly dynamic organelles, exhibiting variations in size and morphology, but also in cellular abundance and function, depending on external stimuli. Importantly, peroxisomes enclose numerous enzymes that regulate lipid metabolism and ROS signaling [180]. Peroxisomal ROS have homeostatic signaling roles, and the wide panel of peroxisomal antioxidant enzymes, including the predominant catalase, controls their effects. ROS produced by peroxisomes crosstalk with mitochondrial ROS signaling [181], being thought to be in excess in cardiometabolic diseases [182]. 
Aging, a crucial risk factor for cardiometabolic diseases, is strongly associated with an accumulation of dysfunctional peroxisomes [183]. Human patients affected by an inherited catalase deficiency were reported to have increased risk to develop age-related diseases, including atherosclerosis [184]. Accordingly, studies conducted in high-fat diet mice models revealed that catalases may improve atherosclerosis [185], and enhanced activity of catalases was observed in foamy cells from rabbit aorta atherosclerotic lesions [186]. Notably, peroxisome-mediated oxidative stress was suggested to contribute to the initial stages of peroxisome dysfunction and cellular senescence in human fibroblasts [187]. Agreeing later studies performed in a model of human cellular aging also revealed that the restoration of the oxidative balance in peroxisomes is associated with a reduction in cellular senescence [188]. As such, peroxisomal homeostasis maintenance via coordination between peroxisome biogenesis and peroxisome selective autophagic degradation (pexophagy) is vital to avoid pathologies such as atherosclerosis, which are related with the accumulation of dysfunctional peroxisomes [180].

The cell cytoskeleton plays an important role in various processes of non-senescent and senescent cells, including the maintenance of cell morphology, cell division, motility and intracellular trafficking. Not surprisingly, senescent cells exhibit alterations in these cellular processes that dictate cytoskeleton changes at the structural and functional levels. Different studies using various types of senescent cells have indicated that increased levels of the intermediate filament protein vimentin contribute to determining the senescent morphology $[189,190]$. Moreover, it has been reported that vimentin is prone to alterations by advanced glycation endproducts (AGEs), suggesting that high levels of vimentin or glycated vimentin may drive pathologies associated with aging. According to this, vimentin accumulation was reported to be related with cataract formation [191]. Regarding the actin filaments, vital to determining cell shape and motility, some changes have been reported to occur during replicative senescence [192-194] but lacking consistency, which may be due to the differential regulation of actin isoforms in the various tissues or be related with variations in the levels of expression with aging [195]. In addition, microtubules, key modulators of intracellular transport, cell division and polarity, were shown to greatly increase during cellular senescence, and multiple microtubule organizing centers (MTOC) were found in some cells [196]. On the contrary, others have presented evidence of decreasing levels of tubulin expression in senescent or aged cells [192,193]. Despite the described evidence linking cellular senescence and modifications in the cytoskeleton during the aging process, studies are required to understand senescence-associated alterations in the cytoskeleton in the context of atherosclerosis.

On the other hand, nuclear changes are well documented in senescent cells, which show prominent and at times multiple nuclei, with severe chromatin condensation detected as large fluorescent punctae in senescent nuclei after staining with $4^{\prime}, 6^{\prime}$-diamidino-2-phenyl-indole (DAPI). These structures, called SAHF, are not exhibited in the nuclei of proliferating cells, where a homogeneous fluorescent staining is observed [197]. In heterochromatin foci, DNA associates with proteins like the heterochromatin protein 1 (HP1) and the methylated lysine 9 histone H3 (H3K9me), being transcriptionally inactive [197,198]. Importantly, genes located in the SAHF, such as the E2F-responsive genes cyclin A and E, which allow cell cycle progression, are not expressed. Remarkably, ectopic overexpression of E2F1 in cells committed to senescence does not turn on the expression of its target genes, showing that SAHF dictates the permanent exit of the cell cycle during cellular senescence [197]. In addition, nuclear lamina assembly is modified in senescent cells, impacting on nuclear stability. In particular, down-regulation of lamin B1, a component of the nuclear lamina, has been reported as a hallmark of senescence in human and murine fibroblast cell lines, suggesting that it could be used as a senescence cell biomarker [199].

Instead, telomere shortening is accompanied by the loss of protective proteins, such as DS-, SS-binding and repair proteins, commonly associated with telomeres. A DNA damage response triggered at short telomeres is verified by the presence of DNA damage response factors, including $r-\mathrm{H} 2 \mathrm{AX}$, at these chromosome regions [200], called telomere dysfunction-induced focus (TIF), being considered a telomere dysfunction marker. Notably, it was reported that $r-\mathrm{H} 2 \mathrm{AX}$ foci form at DNA DSB [201], 
and subsequent studies have shown the link between TIF and cellular senescence. Therefore, TIF has emerged as a potential marker for telomere shortening-induced senescence [202-204].

\subsection{Golgi Complex and the Endoplasmic Reticulum}

The Golgi complex is made up of a series of flattened and interconnected cisternae arranged around the MTOC in the perinuclear region of cells. The highly polarized Golgi apparatus exhibits the cis Golgi network (CGN), receiving cargo from the ER for processing, and the trans Golgi network (TGN), where the cargo exits for export. Both the cytoskeleton and the Golgi matrix proteins contribute to preserving the distinctive Golgi morphology $[205,206]$. Despite the significance of the Golgi complex in regulating various cellular functions, including intracellular transport and involvement in secretory pathways [207], knowledge on its structure in senescent cells was not clearly elucidated until the last decade. Golgi complex was then reported to present a compact structure either in non-senescent and pre-senescent cells, becoming dispersed in senescent cells, suggesting that the Golgi complex structure could be used as another cellular senescence marker [208]. Modifications of the Golgi apparatus morphology were also reported in senescent human cell lines and in aged mouse brain [209,210]. In agreement with this, recent findings demonstrate a disrupted Golgi apparatus morphology and alterations in the transcription of genes involved in Golgi architecture and function in senescent human dermal fibroblasts. Specifically, the Golgi apparatus presented a small and compact morphology in the perinuclear region of non-senescent cells, whereas a large and expanded structure throughout the cytoplasm was displayed by senescent cells [211], indicating a link between Golgi complex functions and the aging process. Importantly, hypertrophy of the Golgi complex and TGN has been reported to be correlated with lysosomal lipid accumulation from oxidized LDL in pigeon and human macrophages, similar to that seen in foam cells of atherosclerotic lesions [212]. These findings point to the need to further elucidate the link between modifications of the Golgi complex structure and function along cellular senescence, and its contribution to atherogenesis.

On the other hand, the ER is an organelle involved in protein folding and post-translational modifications, but also in the regulation of the calcium storage and secretory pathways [213]. The cellular response to ER stress is the UPR, to prevent the accumulation of un/misfolded proteins, relieving ER stress and reestablishing ER homeostasis [214,215]. In contrast, when cells cannot manage the stress and the ER becomes excessively overloaded, the UPR induces autophagy [216] or even apoptosis [217]. Both ER stress and UPR activation were reported to occur during cellular senescence [218], and to be particularly relevant in the replicative senescent phenotype [218-220]. The UPR activation and enlarged ER were also observed in melanocytes undergoing OIS [221]. In addition, the ER expansion and biogenesis were postulated to occur as a cellular attempt to adjust to the increased protein folding demand [222,223]. Later studies revealed that the ER expansion occurs concomitantly with cytoskeleton modifications and subsequent cell size increase [219,224], once again reflecting the interplay between different cellular components. Importantly, convincing findings have also shown that ER stress can prompt inflammatory responses in several age-associated diseases, including atherosclerosis [225]. In particular, the incidence of chronic endothelial ER stress and activation of the UPR have been demonstrated in vivo at arterial sites susceptible to atherosclerosis [226]. Figure 2 illustrates the main morphological and associated functional differences amongst senescent and proliferating cells, also contextualizing the numerous organelle modifications that occur along with the process of cellular senescence. 

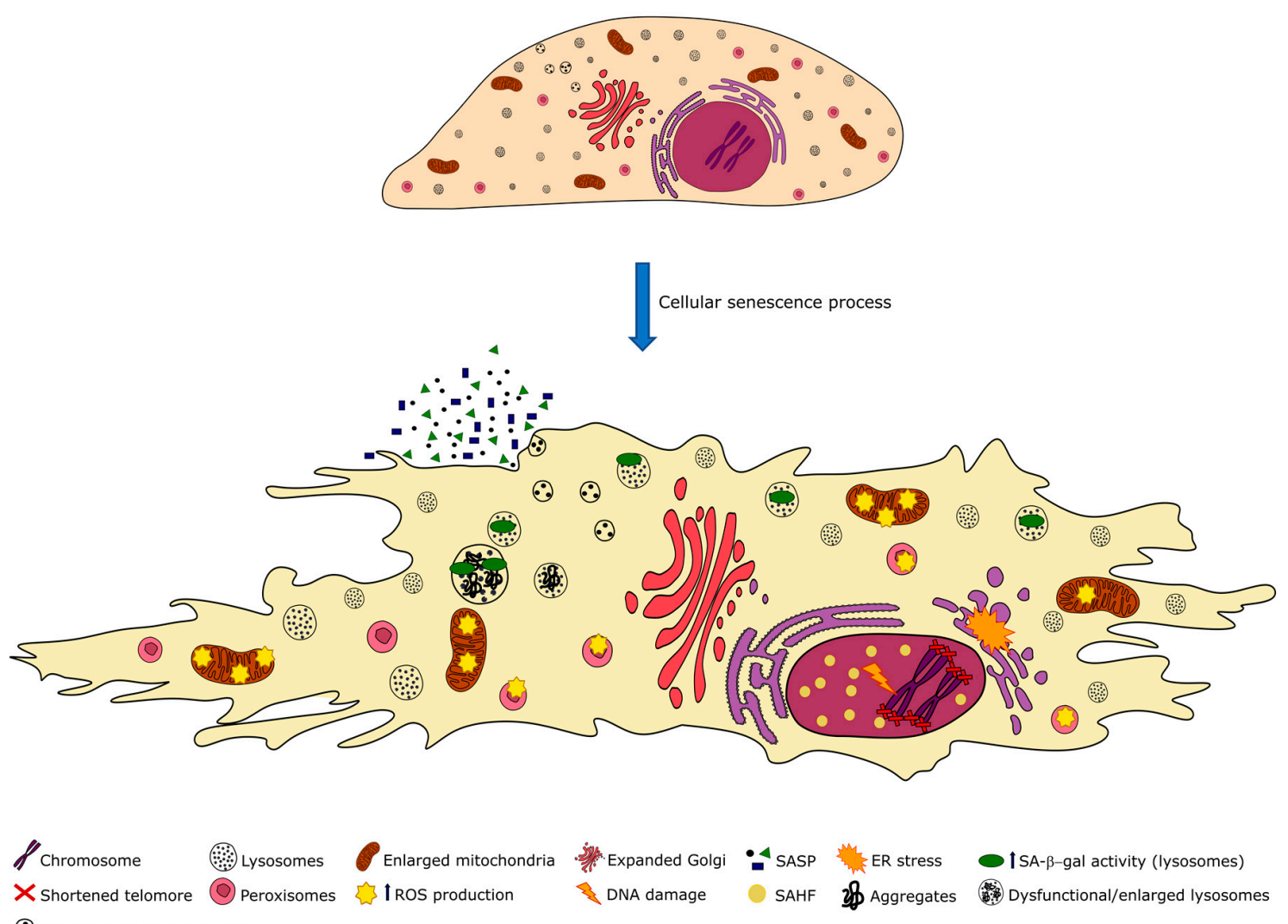

Other intracellular vesicles

Additional senescence-associated modifications:

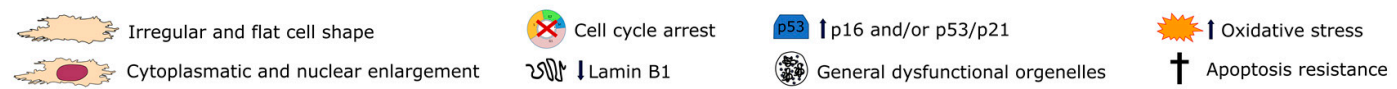

Figure 2. Scheme illustrating the main morphological and related functional differences between a normal proliferating and a senescent cell. Emphasis is given on the multiple organelle modifications occurring during the cellular senescence process, including enlarged lysosomes enclosing lipid and protein aggregates associated with the decline in degradative capacity. Dysfunctional mitochondria and peroxisomes lead to increased ROS generation. An expanded ER and Golgi apparatus are also observed, along with nuclear changes, including severe chromatin condensation. ER-endoplasmic reticulum, SASP-senescent-associated secretory phenotype, ROS-reactive oxygen species, SAHF-senescent-associated heterochromatin foci, SA- $\beta$-gal-senescent-associated $\beta$-galactosidase.

\section{Assessment of Cellular Senescence}

Despite the increasing number of studies in the context of cellular senescence, the lack of specific biological markers to enable the direct detection of senescence has limited the contribution of senescence identification for the clinical diagnostic of senescence-associated diseases. Even the current research of the biological processes involved in cellular senescence is supported by biological markers that allow only indirect identification of senescent cells. The most relevant methodologies currently available to assess cellular senescence are listed in Table 2.

To date, the biomedical research on senescence has had to exploit a combination of senescent cell biomarkers to avoid an imprecise or artefactual detection of senescent cells. Replicative senescence and SIPS confer an identical phenotype, except that SIPS is not associated with telomere attrition, thus being a reversible and not programmed biological process [15]. Detection of cell proliferation markers such as ki67 and the proliferating cell nuclear antigen (PCNA), as well as the incorporation of labelled nucleoside analogues into replicated DNA, are generally used to exclude proliferating cells from analysis. For this purpose, flow cytometry can be performed after immunofluorescence staining of nuclear antigens 
and BrdU incorporation $[227,228]$. Still, the lack of proliferation markers does not guarantee cellular senescence, as this is a common feature of quiescent cells, entailed in a reversible cell-cycle arrest elicited by environmental cues $[229,230]$. Morphology assessment using microscopy techniques can easily be performed to identify the typical senescent cell morphological features, but again the technique cannot confirm senescence per se [228]. In particular, the lysosomal beta-galactosidase activity, regardless of being typically detected at $\mathrm{pH} 4$, can also be detected at higher $\mathrm{pH} 6$ in senescent cells. As such, the SA- $\beta$-gal activity is capable of revealing the lysosomal beta-galactosidase activity and thus the increase in the lysosomal mass in senescent cells [161]. Despite these histochemical and immunohistochemical staining methods being widely used, SA- $\beta$-gal activity is not only present in senescent cells [231,232]. Other indirect biological markers of cell senescence are the expression of genes such as the p16, p21, p53 and $\mathrm{rH} 2 \mathrm{AX}$ that tend to be increased due to the DNA damage associated with the cellular senescence processes [17,31,233-235]. The cell cycle regulators p16, p21, p53 and lamin B1 are generally evaluated using histochemistry, immunohistochemistry and immunoblotting $[199,230,231]$, while the DNA damage marker $\gamma \mathrm{H} 2 \mathrm{AX}$ is regularly assessed either by microscopy or flow cytometry upon immunofluorescence staining $[227,231]$. Heterochromatin markers, namely the HP1 and H3K9me, are other molecular markers of SAHF, which also suggest the occurrence of cellular senescence [235]. SAHF formation is preceded by senescence-associated decondensation satellites (SADs), which are also extensively related to cell senescence [236], and can be analyzed by microscopy following immunofluorescence [237]. Adding to this, the expression and secretion of senescence-associated inflammatory and proteolytic factors (SASP) also allow senescent cell detection [238], using the enzyme-linked immunosorbent assay (ELISA) [231]. Importantly, the majority of senescent cells secrete IL- $1 \alpha$, IL-1 $\beta$, IL-6, IL-8, IL-18 and TNF- $\alpha$ as SASP elements $[21,238,239]$, and these have already been clinically validated as risk factors for the development of CVD [240,241]. On the other hand, ROS-sensing dyes have been reported as being effective for sorting senescent cells [242]. Moreover, the secretion of inflammatory cytokines by senescent cells is supported by the recycling provided by an up-regulation of autophagy [243]. As such, the autophagosome marker microtubule-associated protein light chain 3 (LC3) and the autophagic substrate p62 analysis by immunoblotting is generally used to assess autophagy as a senescence marker [244]. In addition, leukocyte absolute telomere length is also considered a senescence biomarker and can be determined by PCR, FISH or even Southern blot $[245,246]$. Concerning senescent phenotypes, cellular granularity should also be considered. Cellular granularity corresponds to dense particles that are frequently accumulated in the cytoplasm of senescent cells. Although the senescent granule composition varies depending on the cell type and is difficult to determine in research or clinical approaches, they are known to be composed mainly of lysosome-containing lipofuscins [247]. Beta-amyloid granules [248], secretory vesicles [65] and glycogen granules [249-251] are other elements that also contribute to increasing the granule content of senescent cells. While the exact composition of senescent granules requires fine and time-consuming characterization, the quantitative analysis of their accumulation can be easily performed using the side scatter parameter (SSC) during flow cytometry and can therefore be regularly used as an additional senescent cell marker [249]. Remarkably, the lysosomal senescence-associated glycoprotein (SAGP) was recently recognized to be a biomarker of cellular senescence in CVD, but the associated molecular mechanisms still need to be elucidated. It is important to stress that cellular senescence can be induced by several stressing agents in a cell-type dependent manner, justifying the variability of the senescent phenotypes, factors that strongly contribute to the lack of a universal gold-standard senescence marker [46]. Therefore, different parameters should be used to ensure that a cell is senescent, since a single parameter is not sufficient to make this kind of statement. Table 3 shows a comparison of the typical pattern of exhibition of a number of markers by different types of cells, including vascular and post-mitotic senescent cells, reinforcing the need to identify specific markers of senescent cells. 
Table 2. Methodologies used for detection of the most common senescent cell biological markers.

\begin{tabular}{cc}
\hline Biomarkers & Methods Used for Detection \\
\hline Proliferation markers & Flow cytometry \\
Cell morphology & Phase-contrast microscopy \\
SA- $\beta$-Gal & Histochemistry, immunohistochemistry \\
p16, p21, p53, lamin B1 & Histochemistry, immunohistochemistry, immunoblotting \\
SAD2AX & Immunohistochemistry, flow cytometry \\
SASP & Immunohistochemistry \\
ROS & ELISA \\
Autophagic markers & Flow cytometry, microplate readers, microscopy \\
Leukocyte absolute telomere length & Immunoblotting \\
Cellular granularity & PCR, FISH, southern blot \\
\hline
\end{tabular}

SA- $\beta$-Gal-senescence-associated- $\beta$-galactosidase; SADs-senescence-associated decondensation satellites; SAHF-senescence-associated heterochromatin foci; SASP-senescence-associated secretory phenotype; ELISA—enzyme-linked immunosorbent assay; ROS—reactive oxygen species; PCR—polymerase chain reaction; FISH—fluorescence in situ hybridization.

Table 3. Comparison of different markers exhibited by senescent vascular and post-mitotic cells as well as quiescent cells.

\begin{tabular}{cccccc}
\hline Cellular Markers & $\begin{array}{c}\text { Senescent } \\
\text { Vascular SMCs }\end{array}$ & $\begin{array}{c}\text { Senescent } \\
\text { Vascular ECs }\end{array}$ & $\begin{array}{c}\text { Senescent } \\
\text { Monocytes }\end{array}$ & $\begin{array}{c}\text { Post-Mitotic } \\
\text { Cells }\end{array}$ & $\begin{array}{c}\text { Quiescent } \\
\text { Cells }\end{array}$ \\
\hline Cell morphology alterations & + & + & + & + & - \\
Cell cycle arrest & + & + & + & + & reversible \\
Oxidative stress & + & + & + & + & + \\
Apoptosis resistance & + & + & + & non-canonic & - \\
SASP & + & + & + & + & + \\
DNA damage & + & + & + & + \\
\hline
\end{tabular}

SMCs—smooth muscle cells; ECs—endothelial cells; SASP—senescence-associated secretory phenotype.

\section{Senescence-Mediated Therapeutic Strategies for Cardiovascular Disorders}

It is well known that chronic diseases, including atherosclerosis, diabetes, osteoarthritis and dementia, are intrinsically related with aging [252]. In addition, these age-associated diseases are known to be associated with pathological cellular processes including chronic inflammation, organelle dysfunction and cellular senescence [11]. Indeed, senescent cell accumulation in tissues is recognized to compromise the specific physiological functions of the affected organ [253]. For instance, senescent cell accumulation in the aorta has been shown to be associated with vascular hyporeactivity, poor vasomotor function and atherosclerosis [74]. Importantly, cell senescence is able to drive arteriosclerosis independently of aging in human progeria syndromes, characterized by marked early senescent cell accumulation, increased atheroma incidence and a consequent elevated risk for CVD [254-256]. Notably, strategies to promote the clearance of senescent cells from the arterial vessels have been shown to improve the typical age-related vascular phenotypes and therefore may be a potential therapeutic intervention to reduce morbidity and mortality from CVD [74]. From a clinical perspective, senescent cells exist in moderate amounts in aged tissues and are core players in various pathological processes, thus being an attractive target to prevent and treat age and senescent cell-associated CVD. Indeed, efforts have been made to develop senolytic drugs, which selectively remove senescent cells by apoptosis [257]. The tyrosine kinase inhibitor dasatinib and the flavonoid quercetin were the first senolytic drugs to be reported [257]. Initial evidence suggests that senolytic therapies could be administered intermittently and that therapy resistance is unlikely to occur. Remarkably, senescent cells secrete pro-apoptotic factors that neutralize nearby cells, but to which they are resistant, due to the activation of anti-apoptotic pathways. In line with this, it was found that both dasatinib and quercetin, amongst others, are capable of regulating the anti-apoptotic pathways of senescent cells facilitating their elimination in rodent and human cell cultures, fresh human tissue explants and mouse models of aging $[14,253,257,258]$. However, 
the potential of senolytic drugs to regulate anti-apoptotic pathways varies depending on the origin of the senescent cells, and as such the newly discovered drugs do not show the same level of efficiency against all senescent cell types. Promising therapeutic approaches are therefore likely to arise from the targeting of multiple anti-apoptotic signaling pathways, with complex drug cocktails that may be able to neutralize a wider array of senescent cell types. Similar to that occurring in current cancer treatment, these multidimensional treatment modalities are also likely to require exposition to lower levels of each specific drug and contribute to attain a therapeutic synergism.

In addition, even though scarce adverse effects have been perceived in mice exposed to senolytics, adverse effects of some drugs have been documented [253]. The drug navitoclax (ABT263), an anti-cancer agent with senolytic activity, regularly causes neutropenia and thrombocytopenia [253]. Senolytic treatment also poses other hidden challenges; while it can neutralize well-established senescent cells carrying potentially oncogenic mutations and thus hinder cancer development, senolytic approaches have also been reported to affect the protective and anti-carcinogenic cellular senescence mechanisms [258]. Nevertheless, mice treated with a combination of dasatinib and quercetin exhibited increased survival and health span. The administration of senolytics in mice also relieved the onset of physical disabilities, delayed chronic disorders associated with aging and reduced survival upon senescent cell transplantation [258]. In addition, exposure to dasatinib and quercetin was shown to boost vasomotor function and to diminish aortic calcification in aged and hypercholesterolemic mice, respectively [74], significantly improving cardiac function in aged mice [257]. Stimulation of cardiac progenitor cells in aged hearts and increased cardiomyocyte proliferative capacity were also reported upon senescent cell elimination in aged mice, both using pharmacological approaches or in genetic senolytic models [38]. Pharmacological and genetic senolytic models supported a link between senescent cell depletion, inhibition of heart fibrosis and increased cardiomyocyte proliferative expression profile [37]. Furthermore, senescent cardiomyocyte elimination via administration of ABT263 improved myocardiac remodeling and the overall survival rate in a myocardial infarction mouse model [259]. These findings demonstrate that senolysis is able to reverse phenotypic changes associated with aging, namely through the reversion of age-associated cardiac dysfunction and by promoting its regenerative capacity, which reinforces senolysis as a potential strategy to treat CVD $[253,260]$. In addition, cardiac glycosides were recently identified as senolytic compounds, with strong potential to be used in effective treatments against age-associated disorders [261,262]. The HSP90 chaperone inhibitors were also identified as a novel class of senolytics [263], amongst which 17-DMAG was found to ameliorate atherosclerosis in mice [264], potentially due to its senolytic activity. In addition, 2-deoxy-D-glucose (2DG), a glucose analog that inhibits ATP synthesis leading to cell cycle arrest and cell death, was shown to have a senolytic effect on senescent vascular smooth muscle cells. The senolytic effect of 2DG potentially depends on the increased metabolic activity of senescent cells, which may have an impact on the progression of atherosclerosis [76]. Although some senolytics have been clinically approved or are already in clinical trials for oncologic diseases, idiopathic pulmonary fibrosis and chronic kidney disease [265], studies with senolytic drugs have only been performed in animal models of disease in the field of atherosclerosis, and clinical trials are currently awaited.

On the other hand, distinct studies have suggested that suppressing cellular senescence is another potential strategy to develop therapies for cardiovascular disorders. Amongst these, activation of Sirtuin1 (SIRT1) signaling has been consistently reported as being capable of inducing suppression of cellular senescence. Specifically, SIRT1 activation mediated by the polyphenol resveratrol was shown to prevent both arterial wall inflammation and stiffening in nonhuman primates [266]. Likewise, SIRT1 specific activator SRT1720 was shown to alleviate hypertension and arterial stiffness in mice [267]. Important agreeing studies revealed down-regulated SIRT1 expression in VSMCs of patients suffering from abdominal aortic aneurysm, while SIRT1 activation was accompanied by the inhibition of cell senescence and diminished vascular inflammation [268]. Accordingly, calorie restriction was found to be associated with SIRT1 activation in VSMCs and decreased prevalence of abdominal aortic aneurysm [269]. In agreement, other related studies have also demonstrated that the suppression of 
VSMC senescence is mediated by SIRT1 signaling pathways [270,271]. Other clinical treatments for CVD include the drug pioglitazone that stimulates telomerase activation, attenuating EC senescence [272].

Alternative approaches to target senescent cells are also being investigated. These include vaccines and other modulators of the immune system to hasten the elimination of senescent cells, as well as toxin delivery through senescent cell-recognizing technologies. The potential of drugs such as metformin and rapamycin (sirolimus) to inhibit the SASP, diminish the pro-inflammatory drive and the damage caused by activated senescent cells is also being explored [253]. Specifically, metformin [273] and rapamycin [173,274,275] were shown to alleviate CVD. These drugs are considered senostatic or senomorphic drugs, as they inhibit the SASP, preventing the progression of cell senescence, without inducing the death of senescent cells [276]. Regarding the energy-sensing mTOR pathway, its inhibition by rapamycin led to extended mice lifespan, alleviated senescence and exhibited anti-atherosclerotic effects [178,179]. Moreover, decreased arterial expression of the senescence marker p19, age-associated vascular dysfunction and oxidative stress reversal were observed upon dietary intake of rapamycin [277]. A recent study also revealed that $\mathrm{mTORC1}$ inhibition mediated by rapamycin strongly weakened replicative senescence in human cardiac progenitor cells [177], which may open avenues to develop novel therapies. Moreover, statins were reported to inhibit the SASP and participate in the regulation of the cell cycle and telomerase, delaying both EC and T-cell senescence [278]. Interestingly, modulation or removal of senescent cells targeting the marker SAGP was recently postulated as a potential therapy for atherosclerosis.

Importantly, advances have been provided in the development of natural-based bioactive compounds with potential anti-senescence properties, termed nutraceuticals [279]. Polyphenols, abundantly present in plants, exhibit antioxidant and anti-inflammatory properties, thus being potential senostatics by counteracting pro-oxidant and pro-inflammatory signaling in senescent cells [280]. Interestingly, resveratrol, already shown to exhibit cell senescence suppressor properties in the context of cardiovascular complications [266], is found amongst these compounds [280]. As the development of nutraceutical-based senolytics and senostatics to alleviate age-related diseases is being pursued $[279,280]$, hope is put into these additional potential strategies to face CVDs.

On the other hand, mesenchymal stem cell (MSC)-based therapies are also being developed to face senescence-associated CVDs. MSCs are multipotent cells with multi-differentiation potential and low immunogenicity [281]. Notably, clinical trials on MSC transplantation are currently ongoing, suggesting cardiac improvements in subjects with heart failure secondary to ischemic cardiomyopathy [282].

Considering the overall gathered evidence of the potential treatment regiments in the mitigation of pathological cell senescence overruling atherosclerosis (Table 4), great expectation is placed on clinical trials with senolytic agents that are currently being waited for. Clinical trials assessing the safety and efficacy of senolytic drugs may allow further progress to the exciting stages of patient drug administration and provide novel therapies to prevent the development of cell senescence and CVD [20].

Table 4. Senescence-based therapeutic approaches for atherosclerosis and cardiovascular disorders.

\begin{tabular}{|c|c|c|c|}
\hline Therapeutic Strategies & Drugs & Model Species/Clinical Trials & Mechanism of Action \\
\hline \multirow{3}{*}{ Senolytics } & Dasatinib, quercetin, navitoclax & Mouse models & \multirow{3}{*}{$\begin{array}{c}\text { Induction of cellular } \\
\text { apoptosis }\end{array}$} \\
\hline & Cardiac glycosides & Human and mouse models & \\
\hline & 2DG & Human models & \\
\hline \multirow{3}{*}{$\begin{array}{l}\text { Cellular senescence } \\
\text { suppressors }\end{array}$} & Resveratrol & Non-human primate models & \multirow{3}{*}{$\begin{array}{c}\text { Inhibition of cellular } \\
\text { senescence }\end{array}$} \\
\hline & SRT1720 & Mouse models & \\
\hline & Pioglitazone & Human, mouse and bovine models & \\
\hline Senostatics & Rapamycin, metformin, statins & Human and mouse models & SASP inhibition \\
\hline MSC-based & - & Early phase trials & Cell engraftment \\
\hline
\end{tabular}

2DG-2-deoxy-D-glucose; SASP—senescence-associated secretory phenotype; MSC-mesenchymal stem cell. 


\section{Conclusions}

Cell senescence is a complex process involving various cellular components and signaling pathways in a response to diverse physiological events. Cellular senescence is also intrinsically involved in the pathological process of atherosclerosis, regulating various morphological and functional alterations with dramatic consequences for atheroma progression due to SASP.

Despite the great therapeutic advances made to prevent and treat atherosclerosis and CVD, the acute manifestations of these pathologies continue to be associated with an enormous socio-economic burden and the main cause of death worldwide. Targeting senescent cells via a variety of therapeutic approaches, including senolytics and senostatics, has emerged as a promising strategy to mitigate atherogenesis. In this context, targeting the subjacent marked dysfunctional organelles that arise during cellular senescence, namely senescent lysosomes and mitochondria, is key to counteracting senescence-mediated atherosclerotic events. Therefore, better clarification of the role of senescence, the molecular mechanisms involved, and the specific implications of senescent organelles in atherosclerosis is urgently needed, as the challenging clinical trials, so that the best therapeutic approaches can be outlined in the near future.

Author Contributions: O.V.V. proposed and structured the outline of the manuscript. G.M.-O. wrote the majority of the manuscript. O.V.V., C.R. and A.R.A.M. have also contributed to the writing of this manuscript. C.R. designed the Figures 1 and 2. All authors have read and agreed to the published version of the manuscript.

Funding: Our research is supported by national funds through FCT- Fundação para a Ciência e Tecnologia and by PROGRAMAS DE ATIVIDADES CONJUNTAS (PAC) grant numbers PTDC/MED-PAT/29395/2017 and No 03/SAICT/2015. ARAM is supported by the CEECIND/01006/2017, funded by FCT.

Conflicts of Interest: The authors declare no conflict of interest. The funders had no role in the writing of the manuscript.

\section{References}

1. Robinson, J.G.; Fox, K.M.; Bullano, M.F.; Grandy, S. Atherosclerosis profile and incidence of cardiovascular events: A population-based survey. BMC Cardiovasc. Disord. 2009, 9, 46. [CrossRef]

2. Yancey, P.G.; Jerome, W.G. Lysosomal sequestration of free and esterified cholesterol from oxidized low density lipoprotein in macrophages of different species. J. Lipid Res. 1998, 39, 1349-1361. [PubMed]

3. Steinberg, D.; Parthasarathy, S.; Carew, T.E.; Khoo, J.C.; Witztum, J.L. Beyond cholesterol. Modifications of low-density lipoprotein that increase its atherogenicity. N. Engl. J. Med. 1989, 320, 915-924. [PubMed]

4. Lusis, A.J. Atherosclerosis. Nature 2000, 407, 233-241. [CrossRef] [PubMed]

5. Fuster, J.J.; Castillo, A.I.; Zaragoza, C.; Ibanez, B.; Andres, V. Animal models of atherosclerosis. Prog. Mol. Biol. Transl. Sci. 2012, 105, 1-23.

6. Allahverdian, S.; Chaabane, C.; Boukais, K.; Francis, G.A.; Bochaton-Piallat, M.L. Smooth muscle cell fate and plasticity in atherosclerosis. Cardiovasc. Res. 2018, 114, 540-550. [CrossRef]

7. Wada, Y.; Sugiyama, A.; Yamamoto, T.; Naito, M.; Noguchi, N.; Yokoyama, S.; Tsujita, M.; Kawabe, Y.; Kobayashi, M.; Izumi, A.; et al. Lipid accumulation in smooth muscle cells under LDL loading is independent of LDL receptor pathway and enhanced by hypoxic conditions. Arterioscler. Thromb. Vasc. Biol. 2002, 22, 1712-1719. [CrossRef]

8. de Duve, C. The participation of lysosomes in the transformation of smooth muscle cells to foamy cells in the aorta of cholesterol-fed rabbits. Acta Cardiol. 1974, 20, 9-25.

9. Feil, S.; Fehrenbacher, B.; Lukowski, R.; Essmann, F.; Schulze-Osthoff, K.; Schaller, M.; Feil, R. Transdifferentiation of vascular smooth muscle cells to macrophage-like cells during atherogenesis. Circ. Res. 2014, 115, 662-667. [CrossRef]

10. Berliner, J.A.; Navab, M.; Fogelman, A.M.; Frank, J.S.; Demer, L.L.; Edwards, P.A.; Watson, A.D.; Lusis, A.J. Atherosclerosis: Basic mechanisms. Oxidation, inflammation, and genetics. Circulation 1995, 91, 2488-2496. [CrossRef]

11. Kirkland, J.L. Translating the Science of Aging into Therapeutic Interventions. Cold Spring Harb. Perspect. Med. 2016, 6, a025908. [CrossRef] [PubMed] 
12. Bentzon, J.F.; Otsuka, F.; Virmani, R.; Falk, E. Mechanisms of plaque formation and rupture. Circ. Res. 2014, 114, 1852-1866. [CrossRef] [PubMed]

13. Childs, B.G.; Baker, D.J.; Wijshake, T.; Conover, C.A.; Campisi, J.; van Deursen, J.M. Senescent intimal foam cells are deleterious at all stages of atherosclerosis. Science 2016, 354, 472-477. [CrossRef]

14. Childs, B.G.; Li, H.; van Deursen, J.M. Senescent cells: A therapeutic target for cardiovascular disease. J. Clin. Investig. 2018, 128, 1217-1228. [CrossRef] [PubMed]

15. Goligorsky, M.S.; Chen, J.; Patschan, S. Stress-induced premature senescence of endothelial cells: A perilous state between recovery and point of no return. Curr. Opin. Hematol. 2009, 16, 215-219. [CrossRef]

16. Lopez-Otin, C.; Blasco, M.A.; Partridge, L.; Serrano, M.; Kroemer, G. The hallmarks of aging. Cell 2013, 153, 1194-1217. [CrossRef]

17. Munoz-Espin, D.; Serrano, M. Cellular senescence: From physiology to pathology. Nat. Rev. Mol. Cell Biol. 2014, 15, 482-496. [CrossRef]

18. Hernandez-Segura, A.; Nehme, J.; Demaria, M. Hallmarks of Cellular Senescence. Trends Cell Biol. 2018, 28, 436-453. [CrossRef]

19. Byun, H.O.; Lee, Y.K.; Kim, J.M.; Yoon, G. From cell senescence to age-related diseases: Differential mechanisms of action of senescence-associated secretory phenotypes. BMB Rep. 2015, 48, 549-558. [CrossRef]

20. Tchkonia, T.; Kirkland, J.L. Aging, Cell Senescence, and Chronic Disease: Emerging Therapeutic Strategies. JAMA 2018, 320, 1319-1320. [CrossRef]

21. Freund, A.; Orjalo, A.V.; Desprez, P.Y.; Campisi, J. Inflammatory networks during cellular senescence: Causes and consequences. Trends Mol. Med. 2010, 16, 238-246. [CrossRef] [PubMed]

22. Xue, W.; Zender, L.; Miething, C.; Dickins, R.A.; Hernando, E.; Krizhanovsky, V.; Cordon-Cardo, C.; Lowe, S.W. Senescence and tumour clearance is triggered by p53 restoration in murine liver carcinomas. Nature 2007, 445, 656-660. [CrossRef] [PubMed]

23. Baker, D.J.; Childs, B.G.; Durik, M.; Wijers, M.E.; Sieben, C.J.; Zhong, J.; Saltness, R.A.; Jeganathan, K.B.; Verzosa, G.C.; Pezeshki, A.; et al. Naturally occurring p16(Ink4a)-positive cells shorten healthy lifespan. Nature 2016, 530, 184-189. [CrossRef] [PubMed]

24. Bhat, R.; Crowe, E.P.; Bitto, A.; Moh, M.; Katsetos, C.D.; Garcia, F.U.; Johnson, F.B.; Trojanowski, J.Q.; Sell, C.; Torres, C. Astrocyte senescence as a component of Alzheimer's disease. PLoS ONE 2012, 7, e45069. [CrossRef] [PubMed]

25. Ogrodnik, M.; Miwa, S.; Tchkonia, T.; Tiniakos, D.; Wilson, C.L.; Lahat, A.; Day, C.P.; Burt, A.; Palmer, A.; Anstee, Q.M.; et al. Cellular senescence drives age-dependent hepatic steatosis. Nat. Commun. 2017, 8, 15691. [CrossRef]

26. Schafer, M.J.; White, T.A.; Iijima, K.; Haak, A.J.; Ligresti, G.; Atkinson, E.J.; Oberg, A.L.; Birch, J.; Salmonowicz, H.; Zhu, Y.; et al. Cellular senescence mediates fibrotic pulmonary disease. Nat. Commun. 2017, 8, 14532. [CrossRef]

27. Campisi, J. Aging, cellular senescence, and cancer. Annu. Rev. Physiol. 2013, 75, 685-705. [CrossRef]

28. Naylor, R.M.; Baker, D.J.; van Deursen, J.M. Senescent cells: A novel therapeutic target for aging and age-related diseases. Clin. Pharmacol. Ther. 2013, 93, 105-116. [CrossRef]

29. Matthews, C.; Gorenne, I.; Scott, S.; Figg, N.; Kirkpatrick, P.; Ritchie, A.; Goddard, M.; Bennett, M. Vascular smooth muscle cells undergo telomere-based senescence in human atherosclerosis: Effects of telomerase and oxidative stress. Circ. Res. 2006, 99, 156-164. [CrossRef]

30. Vasile, E.; Tomita, Y.; Brown, L.F.; Kocher, O.; Dvorak, H.F. Differential expression of thymosin beta-10 by early passage and senescent vascular endothelium is modulated by VPF/VEGF: Evidence for senescent endothelial cells in vivo at sites of atherosclerosis. FASEB J. 2001, 15, 458-466. [CrossRef]

31. van Deursen, J.M. The role of senescent cells in ageing. Nature 2014, 509, 439-446. [CrossRef]

32. Beauséjour, C.M.; Krtolica, A.; Galimi, F.; Narita, M.; Lowe, S.W.; Yaswen, P.; Campisi, J. Reversal of human cellular senescence: Roles of the p53 and p16 pathways. Embo J. 2003, 22, 4212-4222. [CrossRef] [PubMed]

33. Campisi, J. Senescent cells, tumor suppression, and organismal aging: Good citizens, bad neighbors. Cell 2005, 120, 513-522. [CrossRef] [PubMed]

34. Jacobs, J.J.; de Lange, T. Significant role for p16INK4a in p53-independent telomere-directed senescence. Curr. Biol. 2004, 14, 2302-2308. [CrossRef]

35. Donato, A.J.; Morgan, R.G.; Walker, A.E.; Lesniewski, L.A. Cellular and molecular biology of aging endothelial cells. J. Mol. Cell Cardiol. 2015, 89, 122-135. [CrossRef] 
36. Seoane, M.; Costoya, J.A.; Arce, V.M. Uncoupling Oncogene-Induced Senescence (OIS) and DNA Damage Response (DDR) triggered by DNA hyper-replication: Lessons from primary mouse embryo astrocytes (MEA). Sci. Rep. 2017, 7, 12991. [CrossRef] [PubMed]

37. Anderson, R.; Lagnado, A.; Maggiorani, D.; Walaszczyk, A.; Dookun, E.; Chapman, J.; Birch, J.; Salmonowicz, H.; Ogrodnik, M.; Jurk, D.; et al. Length-independent telomere damage drives post-mitotic cardiomyocyte senescence. Embo J. 2019, 38, e1000492. [CrossRef]

38. Lewis-McDougall, F.C.; Ruchaya, P.J.; Domenjo-Vila, E.; Shin Teoh, T.; Prata, L.; Cottle, B.J.; Clark, J.E.; Punjabi, P.P.; Awad, W.; Torella, D.; et al. Aged-senescent cells contribute to impaired heart regeneration. Aging Cell 2019, 18, e12931. [CrossRef]

39. Campisi, J. Cellular senescence: Putting the paradoxes in perspective. Curr. Opin. Genet. Dev. 2011, 21, 107-112. [CrossRef]

40. Hall, B.M.; Balan, V.; Gleiberman, A.S.; Strom, E.; Krasnov, P.; Virtuoso, L.P.; Rydkina, E.; Vujcic, S.; Balan, K.; Gitlin, I.; et al. Aging of mice is associated with p16(Ink4a)- and $\beta$-galactosidase-positive macrophage accumulation that can be induced in young mice by senescent cells. Aging 2016, 8, 1294-1315. [CrossRef]

41. Kocabas, F.; Zheng, J.; Thet, S.; Copeland, N.G.; Jenkins, N.A.; DeBerardinis, R.J.; Zhang, C.; Sadek, H.A. Meis1 regulates the metabolic phenotype and oxidant defense of hematopoietic stem cells. Blood 2012, 120 , 4963-4972. [CrossRef] [PubMed]

42. Alam, P.; Haile, B.; Arif, M.; Pandey, R.; Rokvic, M.; Nieman, M.; Maliken, B.D.; Paul, A.; Wang, Y.G.; Sadayappan, S.; et al. Inhibition of Senescence-Associated Genes Rb1 and Meis2 in Adult Cardiomyocytes Results in Cell Cycle Reentry and Cardiac Repair Post-Myocardial Infarction. J. Am. Heart Assoc. 2019, 8, e012089. [CrossRef]

43. Chang, Z.S.; Xia, J.B.; Wu, H.Y.; Peng, W.T.; Jiang, F.Q.; Li, J.; Liang, C.Q.; Zhao, H.; Park, K.S.; Song, G.H.; et al. Forkhead box $\mathrm{O} 3$ protects the heart against paraquat-induced aging-associated phenotypes by upregulating the expression of antioxidant enzymes. Aging Cell 2019, 18, e12990. [CrossRef] [PubMed]

44. Cai, B.; Ma, W.; Bi, C.; Yang, F.; Zhang, L.; Han, Z.; Huang, Q.; Ding, F.; Li, Y.; Yan, G.; et al. Long noncoding RNA H19 mediates melatonin inhibition of premature senescence of c-kit(+) cardiac progenitor cells by promoting miR-675. J. Pineal. Res. 2016, 61, 82-95. [CrossRef]

45. Lazzarini, E.; Balbi, C.; Altieri, P.; Pfeffer, U.; Gambini, E.; Canepa, M.; Varesio, L.; Bosco, M.C.; Coviello, D.; Pompilio, G.; et al. The human amniotic fluid stem cell secretome effectively counteracts doxorubicin-induced cardiotoxicity. Sci. Rep. 2016, 6, 29994. [CrossRef]

46. Anderson, R.; Richardson, G.D.; Passos, J.F. Mechanisms driving the ageing heart. Exp. Gerontol. 2018, 109, 5-15. [CrossRef]

47. Sapieha, P.; Mallette, F.A. Cellular Senescence in Postmitotic Cells: Beyond Growth Arrest. Trends Cell Biol. 2018, 28, 595-607. [CrossRef]

48. Coppe, J.P.; Patil, C.K.; Rodier, F.; Sun, Y.; Munoz, D.P.; Goldstein, J.; Nelson, P.S.; Desprez, P.Y.; Campisi, J. Senescence-associated secretory phenotypes reveal cell-nonautonomous functions of oncogenic RAS and the p53 tumor suppressor. PLoS Biol. 2008, 6, 2853-2868. [CrossRef]

49. Feletou, M.; Vanhoutte, P.M. Endothelial dysfunction: A multifaceted disorder (The Wiggers Award Lecture). Am. J. Physiol. Heart Circ. Physiol. 2006, 291, H985-H1002. [CrossRef] [PubMed]

50. Gimbrone, M.A., Jr.; García-Cardeña, G. Endothelial Cell Dysfunction and the Pathobiology of Atherosclerosis. Circ. Res. 2016, 118, 620-636. [CrossRef] [PubMed]

51. Laina, A.; Stellos, K.; Stamatelopoulos, K. Vascular ageing: Underlying mechanisms and clinical implications. Exp. Gerontol. 2018, 109, 16-30. [CrossRef] [PubMed]

52. Minamino, T.; Miyauchi, H.; Yoshida, T.; Ishida, Y.; Yoshida, H.; Komuro, I. Endothelial cell senescence in human atherosclerosis: Role of telomere in endothelial dysfunction. Circulation 2002, 105, 1541-1544. [CrossRef] [PubMed]

53. Bonello-Palot, N.; Simoncini, S.; Robert, S.; Bourgeois, P.; Sabatier, F.; Levy, N.; Dignat-George, F.; Badens, C. Prelamin A accumulation in endothelial cells induces premature senescence and functional impairment. Atherosclerosis 2014, 237, 45-52. [CrossRef] [PubMed]

54. Yentrapalli, R.; Azimzadeh, O.; Kraemer, A.; Malinowsky, K.; Sarioglu, H.; Becker, K.F.; Atkinson, M.J.; Moertl, S.; Tapio, S. Quantitative and integrated proteome and microRNA analysis of endothelial replicative senescence. J. Proteomics 2015, 126, 12-23. [CrossRef] 
55. Zhu, C.; Yu, Y.; Montani, J.P.; Ming, X.F.; Yang, Z. Arginase-I enhances vascular endothelial inflammation and senescence through eNOS-uncoupling. BMC Res. Notes 2017, 10, 82. [CrossRef]

56. Zhang, J.; Patel, J.M.; Block, E.R. Enhanced apoptosis in prolonged cultures of senescent porcine pulmonary artery endothelial cells. Mech. Ageing Dev. 2002, 123, 613-625. [CrossRef]

57. Krouwer, V.J.; Hekking, L.H.; Langelaar-Makkinje, M.; Regan-Klapisz, E.; Post, J.A. Endothelial cell senescence is associated with disrupted cell-cell junctions and increased monolayer permeability. Vasc Cell 2012, 4, 12. [CrossRef]

58. Lowe, D.; Raj, K. Premature aging induced by radiation exhibits pro-atherosclerotic effects mediated by epigenetic activation of CD44 expression. Aging Cell 2014, 13, 900-910. [CrossRef]

59. Warboys, C.M.; de Luca, A.; Amini, N.; Luong, L.; Duckles, H.; Hsiao, S.; White, A.; Biswas, S.; Khamis, R.; Chong, C.K.; et al. Disturbed flow promotes endothelial senescence via a p53-dependent pathway. Arterioscler. Thromb. Vasc. Biol. 2014, 34, 985-995. [CrossRef]

60. Hasegawa, Y.; Saito, T.; Ogihara, T.; Ishigaki, Y.; Yamada, T.; Imai, J.; Uno, K.; Gao, J.; Kaneko, K.; Shimosawa, T.; et al. Blockade of the nuclear factor- $\mathrm{kB}$ pathway in the endothelium prevents insulin resistance and prolongs life spans. Circulation 2012, 125, 1122-1133. [CrossRef]

61. Chien, Y.; Scuoppo, C.; Wang, X.; Fang, X.; Balgley, B.; Bolden, J.E.; Premsrirut, P.; Luo, W.; Chicas, A.; Lee, C.S.; et al. Control of the senescence-associated secretory phenotype by NF- $\mathrm{BB}$ promotes senescence and enhances chemosensitivity. Genes Dev. 2011, 25, 2125-2136. [CrossRef] [PubMed]

62. Salminen, A.; Kauppinen, A.; Kaarniranta, K. Emerging role of NF- $\kappa B$ signaling in the induction of senescence-associated secretory phenotype (SASP). Cell Signal. 2012, 24, 835-845. [CrossRef] [PubMed]

63. Tilstra, J.S.; Robinson, A.R.; Wang, J.; Gregg, S.Q.; Clauson, C.L.; Reay, D.P.; Nasto, L.A.; St Croix, C.M.; Usas, A.; Vo, N.; et al. NF-кB inhibition delays DNA damage-induced senescence and aging in mice. J. Clin. Investig. 2012, 122, 2601-2612. [CrossRef] [PubMed]

64. Minciacchi, V.R.; Freeman, M.R.; Di Vizio, D. Extracellular vesicles in cancer: Exosomes, microvesicles and the emerging role of large oncosomes. Semin. Cell Dev. Biol. 2015, 40, 41-51. [CrossRef]

65. Urbanelli, L.; Buratta, S.; Sagini, K.; Tancini, B.; Emiliani, C. Extracellular Vesicles as New Players in Cellular Senescence. Int. J. Mol. Sci. 2016, 17, 1408. [CrossRef]

66. Lehmann, B.D.; Paine, M.S.; Brooks, A.M.; McCubrey, J.A.; Renegar, R.H.; Wang, R.; Terrian, D.M. Senescence-associated exosome release from human prostate cancer cells. Cancer Res. 2008, 68, 7864-7871. [CrossRef]

67. Alique, M.; Ruiz-Torres, M.P.; Bodega, G.; Noci, M.V.; Troyano, N.; Bohorquez, L.; Luna, C.; Luque, R.; Carmona, A.; Carracedo, J.; et al. Microvesicles from the plasma of elderly subjects and from senescent endothelial cells promote vascular calcification. Aging 2017, 9, 778-789. [CrossRef]

68. Carmona, A.; Guerrero, F.; Buendia, P.; Obrero, T.; Aljama, P.; Carracedo, J. Microvesicles Derived from Indoxyl Sulfate Treated Endothelial Cells Induce Endothelial Progenitor Cells Dysfunction. Front. Physiol. 2017, 8, 666. [CrossRef]

69. Carracedo, J.; Ramirez-Carracedo, R.; Martinez de Toda, I.; Vida, C.; Alique, M.; De la Fuente, M.; Ramirez-Chamond, R. Protein Carbamylation: A Marker Reflecting Increased Age-Related Cell Oxidation. Int. J. Mol. Sci. 2018, 19, 1495. [CrossRef]

70. Basatemur, G.L.; Jorgensen, H.F.; Clarke, M.C.H.; Bennett, M.R.; Mallat, Z. Vascular smooth muscle cells in atherosclerosis. Nat. Rev. Cardiol. 2019, 16,727-744. [CrossRef]

71. Bennett, M.R.; Macdonald, K.; Chan, S.W.; Boyle, J.J.; Weissberg, P.L. Cooperative interactions between RB and p53 regulate cell proliferation, cell senescence, and apoptosis in human vascular smooth muscle cells from atherosclerotic plaques. Circ. Res. 1998, 82, 704-712. [CrossRef] [PubMed]

72. Gorenne, I.; Kavurma, M.; Scott, S.; Bennett, M. Vascular smooth muscle cell senescence in atherosclerosis. Cardiovasc. Res. 2006, 72, 9-17. [CrossRef] [PubMed]

73. Mistry, Y.; Poolman, T.; Williams, B.; Herbert, K.E. A role for mitochondrial oxidants in stress-induced premature senescence of human vascular smooth muscle cells. Redox Biol. 2013, 1, 411-417. [CrossRef] [PubMed]

74. Roos, C.M.; Zhang, B.; Palmer, A.K.; Ogrodnik, M.B.; Pirtskhalava, T.; Thalji, N.M.; Hagler, M.; Jurk, D.; Smith, L.A.; Casaclang-Verzosa, G.; et al. Chronic senolytic treatment alleviates established vasomotor dysfunction in aged or atherosclerotic mice. Aging Cell 2016, 15, 973-977. [CrossRef] 
75. Uryga, A.; Gray, K.; Bennett, M. DNA Damage and Repair in Vascular Disease. Annu. Rev. Physiol. 2016, 78, 45-66. [CrossRef]

76. Gardner, S.E.; Humphry, M.; Bennett, M.R.; Clarke, M.C. Senescent Vascular Smooth Muscle Cells Drive Inflammation Through an Interleukin-1alpha-Dependent Senescence-Associated Secretory Phenotype. Arterioscler. Thromb. Vasc. Biol. 2015, 35, 1963-1974. [CrossRef]

77. Nakano-Kurimoto, R.; Ikeda, K.; Uraoka, M.; Nakagawa, Y.; Yutaka, K.; Koide, M.; Takahashi, T.; Matoba, S.; Yamada, H.; Okigaki, M.; et al. Replicative senescence of vascular smooth muscle cells enhances the calcification through initiating the osteoblastic transition. Am. J. Physiol. Heart Circ. Physiol. 2009, 297, H1673-H1684. [CrossRef]

78. Burton, D.G.; Matsubara, H.; Ikeda, K. Pathophysiology of vascular calcification: Pivotal role of cellular senescence in vascular smooth muscle cells. Exp. Gerontol 2010, 45, 819-824. [CrossRef]

79. Johnson, R.C.; Leopold, J.A.; Loscalzo, J. Vascular calcification: Pathobiological mechanisms and clinical implications. Circ. Res. 2006, 99, 1044-1059. [CrossRef]

80. Wang, J.; Uryga, A.K.; Reinhold, J.; Figg, N.; Baker, L.; Finigan, A.; Gray, K.; Kumar, S.; Clarke, M.; Bennett, M. Vascular Smooth Muscle Cell Senescence Promotes Atherosclerosis and Features of Plaque Vulnerability. Circulation 2015, 132, 1909-1919. [CrossRef]

81. Luo, Z.; Xu, W.; Ma, S.; Qiao, H.; Gao, L.; Zhang, R.; Yang, B.; Qiu, Y.; Chen, J.; Zhang, M.; et al. Moderate Autophagy Inhibits Vascular Smooth Muscle Cell Senescence to Stabilize Progressed Atherosclerotic Plaque via the mTORC1/ULK1/ATG13 Signal Pathway. Oxid. Med. Cell Longev. 2017, 2017, 3018190. [CrossRef] [PubMed]

82. Tan, P.; Wang, Y.J.; Li, S.; Wang, Y.; He, J.Y.; Chen, Y.Y.; Deng, H.Q.; Huang, W.; Zhan, J.K.; Liu, Y.S. The PI3K/Akt/mTOR pathway regulates the replicative senescence of human VSMCs. Mol. Cell Biochem. 2016, 422, 1-10. [CrossRef] [PubMed]

83. Sung, J.Y.; Lee, K.Y.; Kim, J.R.; Choi, H.C. Interaction between mTOR pathway inhibition and autophagy induction attenuates adriamycin-induced vascular smooth muscle cell senescence through decreased expressions of p53/p21/p16. Exp. Gerontol. 2018, 109, 51-58. [CrossRef] [PubMed]

84. Grootaert, M.O.J.; Moulis, M.; Roth, L.; Martinet, W.; Vindis, C.; Bennett, M.R.; De Meyer, G.R.Y. Vascular smooth muscle cell death, autophagy and senescence in atherosclerosis. Cardiovasc. Res. 2018, 114, 622-634. [CrossRef] [PubMed]

85. Nakajima, T.; Schulte, S.; Warrington, K.J.; Kopecky, S.L.; Frye, R.L.; Goronzy, J.J.; Weyand, C.M. T-cell-mediated lysis of endothelial cells in acute coronary syndromes. Circulation 2002, 105, 570-575. [CrossRef]

86. Cawthon, R.M.; Smith, K.R.; O’Brien, E.; Sivatchenko, A.; Kerber, R.A. Association between telomere length in blood and mortality in people aged 60 years or older. Lancet 2003, 361, 393-395. [CrossRef]

87. Benetos, A.; Toupance, S.; Gautier, S.; Labat, C.; Kimura, M.; Rossi, P.M.; Settembre, N.; Hubert, J.; Frimat, L.; Bertrand, B.; et al. Short Leukocyte Telomere Length Precedes Clinical Expression of Atherosclerosis: The Blood-and-Muscle Model. Circ. Res. 2018, 122, 616-623. [CrossRef]

88. Haycock, P.C.; Heydon, E.E.; Kaptoge, S.; Butterworth, A.S.; Thompson, A.; Willeit, P. Leucocyte telomere length and risk of cardiovascular disease: Systematic review and meta-analysis. BMJ 2014, 349, g4227. [CrossRef]

89. Spyridopoulos, I.; Martin-Ruiz, C.; Hilkens, C.; Yadegarfar, M.E.; Isaacs, J.; Jagger, C.; Kirkwood, T.; von Zglinicki, T. CMV seropositivity and T-cell senescence predict increased cardiovascular mortality in octogenarians: Results from the Newcastle 85+ study. Aging Cell 2016, 15, 389-392. [CrossRef]

90. Calvert, P.A.; Liew, T.V.; Gorenne, I.; Clarke, M.; Costopoulos, C.; Obaid, D.R.; O'Sullivan, M.; Shapiro, L.M.; McNab, D.C.; Densem, C.G.; et al. Leukocyte telomere length is associated with high-risk plaques on virtual histology intravascular ultrasound and increased proinflammatory activity. Arterioscler. Thromb. Vasc. Biol. 2011, 31, 2157-2164. [CrossRef]

91. Cudejko, C.; Wouters, K.; Fuentes, L.; Hannou, S.A.; Paquet, C.; Bantubungi, K.; Bouchaert, E.; Vanhoutte, J.; Fleury, S.; Remy, P.; et al. p16INK4a deficiency promotes IL-4-induced polarization and inhibits proinflammatory signaling in macrophages. Blood 2011, 118, 2556-2566. [CrossRef] [PubMed]

92. Hwang, E.S.; Yoon, G.; Kang, H.T. A comparative analysis of the cell biology of senescence and aging. Cell Mol. Life Sci. 2009, 66, 2503-2524. [CrossRef] 
93. Kwon, S.M.; Hong, S.M.; Lee, Y.K.; Min, S.; Yoon, G. Metabolic features and regulation in cell senescence. BMB Rep. 2019, 52, 5-12. [CrossRef]

94. Mazucanti, C.H.; Cabral-Costa, J.V.; Vasconcelos, A.R.; Andreotti, D.Z.; Scavone, C.; Kawamoto, E.M. Longevity Pathways (mTOR, SIRT, Insulin/IGF-1) as Key Modulatory Targets on Aging and Neurodegeneration. Curr. Top. Med. Chem. 2015, 15, 2116-2138. [CrossRef]

95. Cuervo, A.M. Autophagy and aging: Keeping that old broom working. Trends Genet. 2008, $24,604-612$. [CrossRef] [PubMed]

96. Cuervo, A.M.; Wong, E. Chaperone-mediated autophagy: Roles in disease and aging. Cell Res. 2014, 24, 92-104. [CrossRef] [PubMed]

97. Rana, A.; Rera, M.; Walker, D.W. Parkin overexpression during aging reduces proteotoxicity, alters mitochondrial dynamics, and extends lifespan. Proc. Natl. Acad. Sci. USA 2013, 110, 8638-8643. [CrossRef] [PubMed]

98. Kang, H.T.; Park, J.T.; Choi, K.; Kim, Y.; Choi, H.J.C.; Jung, C.W.; Lee, Y.S.; Park, S.C. Chemical screening identifies ATM as a target for alleviating senescence. Nat. Chem. Biol. 2017, 13, 616-623. [CrossRef]

99. Bohnert, K.A.; Kenyon, C. A lysosomal switch triggers proteostasis renewal in the immortal C. elegans germ lineage. Nature 2017, 551, 629-633. [CrossRef] [PubMed]

100. Henze, K.; Martin, W. Evolutionary biology: Essence of mitochondria. Nature 2003, 426, 127-128. [CrossRef]

101. Chan, D.C. Fusion and fission: Interlinked processes critical for mitochondrial health. Annu. Rev. Genet. 2012, 46, 265-287. [CrossRef] [PubMed]

102. Tam, Z.Y.; Gruber, J.; Halliwell, B.; Gunawan, R. Mathematical modeling of the role of mitochondrial fusion and fission in mitochondrial DNA maintenance. PLoS ONE 2013, 8, e76230. [CrossRef]

103. Okamoto, K.; Kondo-Okamoto, N. Mitochondria and autophagy: Critical interplay between the two homeostats. Biochim. Biophys. Acta 2012, 1820, 595-600. [CrossRef] [PubMed]

104. Park, S.Y.; Choi, B.; Cheon, H.; Pak, Y.K.; Kulawiec, M.; Singh, K.K.; Lee, M.S. Cellular aging of mitochondrial DNA-depleted cells. Biochem. Biophys. Res. Commun. 2004, 325, 1399-1405. [CrossRef]

105. Yoon, G.; Kim, H.J.; Yoon, Y.S.; Cho, H.; Lim, I.K.; Lee, J.H. Iron chelation-induced senescence-like growth arrest in hepatocyte cell lines: Association of transforming growth factor beta1 (TGF-beta1)-mediated p27Kip1 expression. Biochem. J. 2002, 366, 613-621. [CrossRef] [PubMed]

106. Yoon, Y.S.; Byun, H.O.; Cho, H.; Kim, B.K.; Yoon, G. Complex II defect via down-regulation of iron-sulfur subunit induces mitochondrial dysfunction and cell cycle delay in iron chelation-induced senescence-associated growth arrest. J. Biol. Chem. 2003, 278, 51577-51586. [CrossRef] [PubMed]

107. Byun, H.O.; Jung, H.J.; Kim, M.J.; Yoon, G. PKCdelta phosphorylation is an upstream event of GSK3 inactivation-mediated ROS generation in TGF-beta1-induced senescence. Free Radic. Res. 2014, 48, 1100-1108. [CrossRef]

108. Yoon, Y.S.; Lee, J.H.; Hwang, S.C.; Choi, K.S.; Yoon, G. TGF beta1 induces prolonged mitochondrial ROS generation through decreased complex IV activity with senescent arrest in Mv1Lu cells. Oncogene 2005, 24, 1895-1903. [CrossRef]

109. Byun, H.O.; Jung, H.J.; Seo, Y.H.; Lee, Y.K.; Hwang, S.C.; Hwang, E.S.; Yoon, G. GSK3 inactivation is involved in mitochondrial complex IV defect in transforming growth factor (TGF) beta1-induced senescence. Exp. Cell Res. 2012, 318, 1808-1819. [CrossRef]

110. Lafargue, A.; Degorre, C.; Corre, I.; Alves-Guerra, M.C.; Gaugler, M.H.; Vallette, F.; Pecqueur, C.; Paris, F. Ionizing radiation induces long-term senescence in endothelial cells through mitochondrial respiratory complex II dysfunction and superoxide generation. Free Radic. Biol. Med. 2017, 108, 750-759. [CrossRef]

111. Wu, W.B.; Menon, R.; Xu, Y.Y.; Zhao, J.R.; Wang, Y.L.; Liu, Y.; Zhang, H.J. Downregulation of peroxiredoxin-3 by hydrophobic bile acid induces mitochondrial dysfunction and cellular senescence in human trophoblasts. Sci. Rep. 2016, 6, 38946. [CrossRef]

112. Correia-Melo, C.; Marques, F.D.; Anderson, R.; Hewitt, G.; Hewitt, R.; Cole, J.; Carroll, B.M.; Miwa, S.; Birch, J.; Merz, A.; et al. Mitochondria are required for pro-ageing features of the senescent phenotype. Embo J. 2016, 35, 724-742. [CrossRef]

113. Murakoshi, M.; Osamura, Y.; Watanabe, K. Mitochondrial alterations in aged rat adrenal cortical cells. Tokai J. Exp. Clin. Med. 1985, 10, 531-536.

114. Tandler, B.; Hoppel, C.L. Studies on giant mitochondria. Ann. N. Y. Acad. Sci. 1986, 488, 65-81. [CrossRef] 
115. Yoon, Y.S.; Yoon, D.S.; Lim, I.K.; Yoon, S.H.; Chung, H.Y.; Rojo, M.; Malka, F.; Jou, M.J.; Martinou, J.C.; Yoon, G. Formation of elongated giant mitochondria in DFO-induced cellular senescence: Involvement of enhanced fusion process through modulation of Fis1. J. Cell Physiol. 2006, 209, 468-480. [CrossRef]

116. Kim, Y.M.; Shin, H.T.; Seo, Y.H.; Byun, H.O.; Yoon, S.H.; Lee, I.K.; Hyun, D.H.; Chung, H.Y.; Yoon, G. Sterol regulatory element-binding protein (SREBP)-1-mediated lipogenesis is involved in cell senescence. J. Biol. Chem. 2010, 285, 29069-29077. [CrossRef] [PubMed]

117. Kang, H.T.; Hwang, E.S. Nicotinamide enhances mitochondria quality through autophagy activation in human cells. Aging Cell 2009, 8, 426-438. [CrossRef] [PubMed]

118. Kurz, T.; Terman, A.; Gustafsson, B.; Brunk, U.T. Lysosomes and oxidative stress in aging and apoptosis. Biochim. Biophys. Acta 2008, 1780, 1291-1303. [CrossRef] [PubMed]

119. Bota, D.A.; Davies, K.J. Protein degradation in mitochondria: Implications for oxidative stress, aging and disease: A novel etiological classification of mitochondrial proteolytic disorders. Mitochondrion 2001, 1, 33-49. [CrossRef]

120. Twig, G.; Elorza, A.; Molina, A.J.; Mohamed, H.; Wikstrom, J.D.; Walzer, G.; Stiles, L.; Haigh, S.E.; Katz, S.; Las, G.; et al. Fission and selective fusion govern mitochondrial segregation and elimination by autophagy. Embo J. 2008, 27, 433-446. [CrossRef]

121. Lee, B.Y.; Han, J.A.; Im, J.S.; Morrone, A.; Johung, K.; Goodwin, E.C.; Kleijer, W.J.; DiMaio, D.; Hwang, E.S. Senescence-associated beta-galactosidase is lysosomal beta-galactosidase. Aging Cell 2006, 5, 187-195. [CrossRef] [PubMed]

122. Patschan, S.; Chen, J.; Polotskaia, A.; Mendelev, N.; Cheng, J.; Patschan, D.; Goligorsky, M.S. Lipid mediators of autophagy in stress-induced premature senescence of endothelial cells. Am. J. Physiol. Heart Circ. Physiol. 2008, 294, H1119-H1129. [CrossRef] [PubMed]

123. Manzella, N.; Santin, Y.; Maggiorani, D.; Martini, H.; Douin-Echinard, V.; Passos, J.F.; Lezoualc'h, F.; Binda, C.; Parini, A.; Mialet-Perez, J. Monoamine oxidase-A is a novel driver of stress-induced premature senescence through inhibition of parkin-mediated mitophagy. Aging Cell 2018, 17, e12811. [CrossRef]

124. Lee, H.C.; Lu, C.Y.; Fahn, H.J.; Wei, Y.H. Aging- and smoking-associated alteration in the relative content of mitochondrial DNA in human lung. FEBS Lett. 1998, 441, 292-296. [CrossRef]

125. Wei, Y.H.; Lee, C.F.; Lee, H.C.; Ma, Y.S.; Wang, C.W.; Lu, C.Y.; Pang, C.Y. Increases of mitochondrial mass and mitochondrial genome in association with enhanced oxidative stress in human cells harboring 4,977 BP-deleted mitochondrial DNA. Ann. N. Y. Acad. Sci. 2001, 928, 97-112. [CrossRef]

126. Ballinger, S.W. Beyond retrograde and anterograde signalling: Mitochondrial-nuclear interactions as a means for evolutionary adaptation and contemporary disease susceptibility. Biochem. Soc. Trans. 2013, 41, 111-117. [CrossRef]

127. Jones, A.W.; Yao, Z.; Vicencio, J.M.; Karkucinska-Wieckowska, A.; Szabadkai, G. PGC-1 family coactivators and cell fate: Roles in cancer, neurodegeneration, cardiovascular disease and retrograde mitochondria-nucleus signalling. Mitochondrion 2012, 12, 86-99. [CrossRef]

128. Poyton, R.O.; McEwen, J.E. Crosstalk between nuclear and mitochondrial genomes. Annu. Rev. Biochem. 1996, 65, 563-607. [CrossRef]

129. Finley, L.W.; Haigis, M.C. The coordination of nuclear and mitochondrial communication during aging and calorie restriction. Ageing Res. Rev. 2009, 8, 173-188. [CrossRef]

130. Biswas, G.; Adebanjo, O.A.; Freedman, B.D.; Anandatheerthavarada, H.K.; Vijayasarathy, C.; Zaidi, M.; Kotlikoff, M.; Avadhani, N.G. Retrograde Ca2+ signaling in C2C12 skeletal myocytes in response to mitochondrial genetic and metabolic stress: A novel mode of inter-organelle crosstalk. Embo J. 1999, 18, 522-533. [CrossRef]

131. Butow, R.A.; Avadhani, N.G. Mitochondrial signaling: The retrograde response. Mol. Cell 2004, 14, 1-15. [CrossRef]

132. Chae, S.; Ahn, B.Y.; Byun, K.; Cho, Y.M.; Yu, M.H.; Lee, B.; Hwang, D.; Park, K.S. A systems approach for decoding mitochondrial retrograde signaling pathways. Sci. Signal. 2013, 6, rs4. [CrossRef] [PubMed]

133. Jazwinski, S.M.; Kriete, A. The yeast retrograde response as a model of intracellular signaling of mitochondrial dysfunction. Front. Physiol. 2012, 3, 139. [CrossRef] [PubMed]

134. Finkel, T.; Holbrook, N.J. Oxidants, oxidative stress and the biology of ageing. Nature 2000, 408, $239-247$. [CrossRef] [PubMed] 
135. Lee, H.C.; Wei, Y.H. Mitochondrial alterations, cellular response to oxidative stress and defective degradation of proteins in aging. Biogerontology 2001, 2, 231-244. [CrossRef]

136. Raha, S.; Robinson, B.H. Mitochondria, oxygen free radicals, disease and ageing. Trends Biochem. Sci. 2000, 25, 502-508. [CrossRef]

137. Sohal, R.S.; Ku, H.H.; Agarwal, S.; Forster, M.J.; Lal, H. Oxidative damage, mitochondrial oxidant generation and antioxidant defenses during aging and in response to food restriction in the mouse. Mech. Ageing Dev. 1994, 74, 121-133. [CrossRef]

138. Henle, E.S.; Han, Z.; Tang, N.; Rai, P.; Luo, Y.; Linn, S. Sequence-specific DNA cleavage by Fe2+-mediated fenton reactions has possible biological implications. J. Biol. Chem. 1999, 274, 962-971. [CrossRef]

139. Oikawa, S.; Tada-Oikawa, S.; Kawanishi, S. Site-specific DNA damage at the GGG sequence by UVA involves acceleration of telomere shortening. Biochemistry 2001, 40, 4763-4768. [CrossRef]

140. Ivanov, A.; Pawlikowski, J.; Manoharan, I.; van Tuyn, J.; Nelson, D.M.; Rai, T.S.; Shah, P.P.; Hewitt, G.; Korolchuk, V.I.; Passos, J.F.; et al. Lysosome-mediated processing of chromatin in senescence. J. Cell Biol. 2013, 202, 129-143. [CrossRef]

141. Yang, G.; Lei, Y.; Inoue, A.; Piao, L.; Hu, L.; Jiang, H.; Sasaki, T.; Wu, H.; Xu, W.; Yu, C.; et al. Exenatide mitigated diet-induced vascular aging and atherosclerotic plaque growth in ApoE-deficient mice under chronic stress. Atherosclerosis 2017, 264, 1-10. [CrossRef] [PubMed]

142. Dou, Z.; Ghosh, K.; Vizioli, M.G.; Zhu, J.; Sen, P.; Wangensteen, K.J.; Simithy, J.; Lan, Y.; Lin, Y.; Zhou, Z.; et al. Cytoplasmic chromatin triggers inflammation in senescence and cancer. Nature 2017, 550, 402-406. [CrossRef] [PubMed]

143. Gluck, S.; Guey, B.; Gulen, M.F.; Wolter, K.; Kang, T.W.; Schmacke, N.A.; Bridgeman, A.; Rehwinkel, J.; Zender, L.; Ablasser, A. Innate immune sensing of cytosolic chromatin fragments through cGAS promotes senescence. Nat. Cell Biol. 2017, 19, 1061-1070. [CrossRef] [PubMed]

144. Vizioli, M.G.; Liu, T.; Miller, K.N.; Robertson, N.A.; Gilroy, K.; Lagnado, A.B.; Perez-Garcia, A.; Kiourtis, C.; Dasgupta, N.; Lei, X.; et al. Mitochondria-to-nucleus retrograde signaling drives formation of cytoplasmic chromatin and inflammation in senescence. Genes Dev. 2020, 34, 428-445. [CrossRef]

145. Gorgoulis, V.G.; Pefani, D.E.; Pateras, I.S.; Trougakos, I.P. Integrating the DNA damage and protein stress responses during cancer development and treatment. J. Pathol. 2018, 246, 12-40. [CrossRef]

146. Quijano, C.; Cao, L.; Fergusson, M.M.; Romero, H.; Liu, J.; Gutkind, S.; Rovira, I.I.; Mohney, R.P.; Karoly, E.D.; Finkel, T. Oncogene-induced senescence results in marked metabolic and bioenergetic alterations. Cell Cycle 2012, 11, 1383-1392. [CrossRef] [PubMed]

147. Carmona-Gutierrez, D.; Hughes, A.L.; Madeo, F.; Ruckenstuhl, C. The crucial impact of lysosomes in aging and longevity. Ageing Res. Rev. 2016, 32, 2-12. [CrossRef]

148. Saftig, P.; Klumperman, J. Lysosome biogenesis and lysosomal membrane proteins: Trafficking meets function. Nat. Rev. Mol. Cell Biol. 2009, 10, 623-635. [CrossRef]

149. Comings, D.E.; Okada, T.A. Electron microscopy of human fibroblasts in tissue culture during logarithmic and confluent stages of growth. Exp. Cell Res. 1970, 61, 295-301. [CrossRef]

150. Lipetz, J.; Cristofalo, V.J. Ultrastructural changes accompanying the aging of human diploid cells in culture. J. Ultrastruct. Res. 1972, 39, 43-56. [CrossRef]

151. De Priester, W.; Van Manen, R.; Knook, D.L. Lysosomal activity in the aging rat liver: II. Morphometry of acid phosphatase positive dense bodies. Mech. Ageing Dev. 1984, 26, 205-216. [CrossRef]

152. Porta, E.A.; Sablan, H.M.; Joun, N.S.; Chee, G. Effects of the type of dietary fat at two levels of vitamin E in Wistar male rats during development and aging. IV. Biochemical and morphometric parameters of the heart. Mech. Ageing Dev. 1982, 18, 159-199. [CrossRef]

153. Schmucker, D.L.; Sachs, H. Quantifying dense bodies and lipofuscin during aging: A morphologist's perspective. Arch. Gerontol. Geriatr. 2002, 34, 249-261. [CrossRef]

154. Terman, A.; Dalen, H.; Eaton, J.W.; Neuzil, J.; Brunk, U.T. Mitochondrial recycling and aging of cardiac myocytes: The role of autophagocytosis. Exp. Gerontol. 2003, 38, 863-876. [CrossRef]

155. McHugh, D.; Gil, J. Senescence and aging: Causes, consequences, and therapeutic avenues. J. Cell Biol. 2018, 217, 65-77. [CrossRef] [PubMed]

156. Robbins, E.; Levine, E.M.; Eagle, H. Morphologic changes accompanying senescence of cultured human diploid cells. J. Exp. Med. 1970, 131, 1211-1222. [CrossRef] 
157. Knook, D.L.; Sleyster, E.C. Lysosomal enzyme activities in parenchymal and nonparenchymal liver cells isolated from young, adult and old rats. Mech. Ageing Dev. 1976, 5, 389-398. [CrossRef]

158. Sanchez-Martin, M.M.; Cabezas, J.A. Evaluation of the activities of eight lysosomal hydrolases in sera of humans, rats and pigs of different ages. Mech. Ageing Dev. 1997, 99, 95-107. [CrossRef]

159. Johung, K.; Goodwin, E.C.; DiMaio, D. Human papillomavirus E7 repression in cervical carcinoma cells initiates a transcriptional cascade driven by the retinoblastoma family, resulting in senescence. J. Virol. 2007, 81, 2102-2116. [CrossRef]

160. Sato, Y.; Suzuki, Y.; Ito, E.; Shimazaki, S.; Ishida, M.; Yamamoto, T.; Yamamoto, H.; Toda, T.; Suzuki, M.; Suzuki, A.; et al. Identification and characterization of an increased glycoprotein in aging: Age-associated translocation of cathepsin D. Mech. Ageing Dev. 2006, 127, 771-778. [CrossRef]

161. Dimri, G.P.; Lee, X.; Basile, G.; Acosta, M.; Scott, G.; Roskelley, C.; Medrano, E.E.; Linskens, M.; Rubelj, I.; Pereira-Smith, O.; et al. A biomarker that identifies senescent human cells in culture and in aging skin in vivo. Proc. Natl. Acad. Sci. USA 1995, 92, 9363-9367. [CrossRef] [PubMed]

162. Liu, J.; Lu, W.; Reigada, D.; Nguyen, J.; Laties, A.M.; Mitchell, C.H. Restoration of lysosomal pH in RPE cells from cultured human and ABCA4(-/-) mice: Pharmacologic approaches and functional recovery. Investig. Ophthalmol. Vis. Sci. 2008, 49,772-780. [CrossRef] [PubMed]

163. Buttner, S.; Faes, L.; Reichelt, W.N.; Broeskamp, F.; Habernig, L.; Benke, S.; Kourtis, N.; Ruli, D.; Carmona-Gutierrez, D.; Eisenberg, T.; et al. The Ca2+/Mn2+ ion-pump PMR1 links elevation of cytosolic $\mathrm{Ca}(2+)$ levels to alpha-synuclein toxicity in Parkinson's disease models. Cell Death Differ. 2013, 20, 465-477. [CrossRef] [PubMed]

164. Nixon, R.A. The role of autophagy in neurodegenerative disease. Nat. Med. 2013, 19, 983-997. [CrossRef]

165. Schneider, J.L.; Cuervo, A.M. Autophagy and human disease: Emerging themes. Curr. Opin. Genet. Dev. 2014, 26, 16-23. [CrossRef]

166. Ahmad, F.; Leake, D.S. Lysosomal oxidation of LDL alters lysosomal pH, induces senescence, and increases secretion of pro-inflammatory cytokines in human macrophages. J. Lipid Res. 2019, 60, 98-110. [CrossRef]

167. Carroll, B.; Hewitt, G.; Korolchuk, V.I. Autophagy and ageing: Implications for age-related neurodegenerative diseases. Essays Biochem. 2013, 55, 119-131.

168. Sergin, I.; Bhattacharya, S.; Emanuel, R.; Esen, E.; Stokes, C.J.; Evans, T.D.; Arif, B.; Curci, J.A.; Razani, B. Inclusion bodies enriched for p62 and polyubiquitinated proteins in macrophages protect against atherosclerosis. Sci. Signal. 2016, 9, ra2. [CrossRef]

169. Raught, B.; Gingras, A.C.; Sonenberg, N. The target of rapamycin (TOR) proteins. Proc. Natl. Acad. Sci. USA 2001, 98, 7037-7044. [CrossRef]

170. Noda, T.; Ohsumi, Y. Tor, a phosphatidylinositol kinase homologue, controls autophagy in yeast. J. Biol. Chem. 1998, 273, 3963-3966. [CrossRef]

171. Schmelzle, T.; Hall, M.N. TOR, a central controller of cell growth. Cell 2000, 103, 253-262. [CrossRef]

172. Wullschleger, S.; Loewith, R.; Hall, M.N. TOR signaling in growth and metabolism. Cell 2006, 124, 471-484. [CrossRef] [PubMed]

173. Li, J.; Kim, S.G.; Blenis, J. Rapamycin: One drug, many effects. Cell Metab. 2014, 19, 373-379. [CrossRef]

174. Carroll, B.; Nelson, G.; Rabanal-Ruiz, Y.; Kucheryavenko, O.; Dunhill-Turner, N.A.; Chesterman, C.C.; Zahari, Q.; Zhang, T.; Conduit, S.E.; Mitchell, C.A.; et al. Persistent mTORC1 signaling in cell senescence results from defects in amino acid and growth factor sensing. J. Cell Biol. 2017, 216, 1949-1957. [CrossRef] [PubMed]

175. Laberge, R.M.; Sun, Y.; Orjalo, A.V.; Patil, C.K.; Freund, A.; Zhou, L.; Curran, S.C.; Davalos, A.R.; Wilson-Edell, K.A.; Liu, S.; et al. MTOR regulates the pro-tumorigenic senescence-associated secretory phenotype by promoting IL1A translation. Nat. Cell Biol. 2015, 17, 1049-1061. [CrossRef] [PubMed]

176. Dominick, G.; Bowman, J.; Li, X.; Miller, R.A.; Garcia, G.G. mTOR regulates the expression of DNA damage response enzymes in long-lived Snell dwarf, GHRKO, and PAPPA-KO mice. Aging Cell 2017, 16, 52-60. [CrossRef] [PubMed]

177. Park, J.H.; Lee, N.K.; Lim, H.J.; Ji, S.T.; Kim, Y.J.; Jang, W.B.; Kim, D.Y.; Kang, S.; Yun, J.; Ha, J.S.; et al. Pharmacological inhibition of mTOR attenuates replicative cell senescence and improves cellular function via regulating the STAT3-PIM1 axis in human cardiac progenitor cells. Exp. Mol. Med. 2020, 52, 615-628. [CrossRef] 
178. Walters, H.E.; Deneka-Hannemann, S.; Cox, L.S. Reversal of phenotypes of cellular senescence by pan-mTOR inhibition. Aging 2016, 8, 231-244. [CrossRef] [PubMed]

179. Evangelisti, C.; Cenni, V.; Lattanzi, G. Potential therapeutic effects of the MTOR inhibitors for preventing ageing and progeria-related disorders. Br. J. Clin. Pharmacol. 2016, 82, 1229-1244. [CrossRef] [PubMed]

180. Lodhi, I.J.; Semenkovich, C.F. Peroxisomes: A nexus for lipid metabolism and cellular signaling. Cell Metab 2014, 19, 380-392. [CrossRef] [PubMed]

181. Wang, B.; Van Veldhoven, P.P.; Brees, C.; Rubio, N.; Nordgren, M.; Apanasets, O.; Kunze, M.; Baes, M.; Agostinis, P.; Fransen, M. Mitochondria are targets for peroxisome-derived oxidative stress in cultured mammalian cells. Free Radic. Biol. Med. 2013, 65, 882-894. [CrossRef] [PubMed]

182. Schrader, M.; Fahimi, H.D. Peroxisomes and oxidative stress. Biochim. Biophys. Acta 2006, 1763, 1755-1766. [CrossRef] [PubMed]

183. Titorenko, V.I.; Terlecky, S.R. Peroxisome metabolism and cellular aging. Traffic 2011, 12, 252-259. [CrossRef] [PubMed]

184. Góth, L.; Eaton, J.W. Hereditary catalase deficiencies and increased risk of diabetes. Lancet 2000, 356, 1820-1821. [CrossRef]

185. Yang, H.; Roberts, L.J.; Shi, M.J.; Zhou, L.C.; Ballard, B.R.; Richardson, A.; Guo, Z.M. Retardation of atherosclerosis by overexpression of catalase or both $\mathrm{Cu} / \mathrm{Zn}$-superoxide dismutase and catalase in mice lacking apolipoprotein E. Circ. Res. 2004, 95, 1075-1081. [CrossRef]

186. Chen, H.; Yu, M.; Li, M.; Zhao, R.; Zhu, Q.; Zhou, W.; Lu, M.; Lu, Y.; Zheng, T.; Jiang, J.; et al. Polymorphic variations in manganese superoxide dismutase (MnSOD), glutathione peroxidase-1 (GPX1), and catalase (CAT) contribute to elevated plasma triglyceride levels in Chinese patients with type 2 diabetes or diabetic cardiovascular disease. Mol. Cell Biochem. 2012, 363, 85-91. [CrossRef]

187. Legakis, J.E.; Koepke, J.I.; Jedeszko, C.; Barlaskar, F.; Terlecky, L.J.; Edwards, H.J.; Walton, P.A.; Terlecky, S.R. Peroxisome senescence in human fibroblasts. Mol. Biol. Cell 2002, 13, 4243-4255. [CrossRef]

188. Koepke, J.I.; Nakrieko, K.A.; Wood, C.S.; Boucher, K.K.; Terlecky, L.J.; Walton, P.A.; Terlecky, S.R. Restoration of peroxisomal catalase import in a model of human cellular aging. Traffic 2007, 8, 1590-1600. [CrossRef]

189. Wang, E. Are cross-bridging structures involved in the bundle formation of intermediate filaments and the decrease in locomotion that accompany cell aging? J. Cell Biol. 1985, 100, 1466-1473. [CrossRef]

190. Nishio, K.; Inoue, A.; Qiao, S.; Kondo, H.; Mimura, A. Senescence and cytoskeleton: Overproduction of vimentin induces senescent-like morphology in human fibroblasts. Histochem. Cell Biol. 2001, 116, 321-327. [CrossRef]

191. Capetanaki, Y.; Smith, S.; Heath, J.P. Overexpression of the vimentin gene in transgenic mice inhibits normal lens cell differentiation. J. Cell Biol. 1989, 109, 1653-1664. [CrossRef] [PubMed]

192. Nishio, K.; Inoue, A. Senescence-associated alterations of cytoskeleton: Extraordinary production of vimentin that anchors cytoplasmic p53 in senescent human fibroblasts. Histochem. Cell Biol. 2005, 123, 263-273. [CrossRef] [PubMed]

193. Oender, K.; Trost, A.; Lanschuetzer, C.; Laimer, M.; Emberger, M.; Breitenbach, M.; Richter, K.; Hintner, H.; Bauer, J.W. Cytokeratin-related loss of cellular integrity is not a major driving force of human intrinsic skin aging. Mech. Ageing Dev. 2008, 129, 563-571. [CrossRef]

194. Arnesen, S.M.; Lawson, M.A. Age-related changes in focal adhesions lead to altered cell behavior in tendon fibroblasts. Mech. Ageing Dev. 2006, 127, 726-732. [CrossRef]

195. Gromov, P.; Skovgaard, G.L.; Palsdottir, H.; Gromova, I.; Ostergaard, M.; Celis, J.E. Protein profiling of the human epidermis from the elderly reveals up-regulation of a signature of interferon-gamma-induced polypeptides that includes manganese-superoxide dismutase and the p85beta subunit of phosphatidylinositol 3-kinase. Mol. Cell Proteom. 2003, 2, 70-84. [CrossRef]

196. Wang, E.; Gundersen, D. Increased organization of cytoskeleton accompanying the aging of human fibroblasts in vitro. Exp. Cell Res. 1984, 154, 191-202. [CrossRef]

197. Narita, M.; Nunez, S.; Heard, E.; Narita, M.; Lin, A.W.; Hearn, S.A.; Spector, D.L.; Hannon, G.J.; Lowe, S.W. $\mathrm{Rb}$-mediated heterochromatin formation and silencing of E2F target genes during cellular senescence. Cell 2003, 113, 703-716. [CrossRef]

198. Zhang, R.; Poustovoitov, M.V.; Ye, X.; Santos, H.A.; Chen, W.; Daganzo, S.M.; Erzberger, J.P.; Serebriiskii, I.G.; Canutescu, A.A.; Dunbrack, R.L.; et al. Formation of MacroH2A-containing senescence-associated heterochromatin foci and senescence driven by ASF1a and HIRA. Dev. Cell 2005, 8, 19-30. [CrossRef] 
199. Freund, A.; Laberge, R.M.; Demaria, M.; Campisi, J. Lamin B1 loss is a senescence-associated biomarker. Mol. Biol. Cell 2012, 23, 2066-2075. [CrossRef]

200. Takai, H.; Smogorzewska, A.; de Lange, T. DNA damage foci at dysfunctional telomeres. Curr. Biol. 2003, 13, 1549-1556. [CrossRef]

201. Rogakou, E.P.; Boon, C.; Redon, C.; Bonner, W.M. Megabase chromatin domains involved in DNA double-strand breaks in vivo. J. Cell Biol. 1999, 146, 905-916. [CrossRef]

202. d'Adda di Fagagna, F.; Reaper, P.M.; Clay-Farrace, L.; Fiegler, H.; Carr, P.; Von Zglinicki, T.; Saretzki, G.; Carter, N.P.; Jackson, S.P. A DNA damage checkpoint response in telomere-initiated senescence. Nature 2003, 426, 194-198. [CrossRef]

203. Herbig, U.; Jobling, W.A.; Chen, B.P.; Chen, D.J.; Sedivy, J.M. Telomere shortening triggers senescence of human cells through a pathway involving ATM, p53, and p21(CIP1), but not p16(INK4a). Mol. Cell 2004, 14, 501-513. [CrossRef]

204. Sedelnikova, O.A.; Horikawa, I.; Zimonjic, D.B.; Popescu, N.C.; Bonner, W.M.; Barrett, J.C. Senescing human cells and ageing mice accumulate DNA lesions with unrepairable double-strand breaks. Nat. Cell Biol. 2004, 6, 168-170. [CrossRef]

205. Klumperman, J. Architecture of the mammalian Golgi. Cold Spring Harb. Perspect. Biol. 2011, 3, a005181. [CrossRef] [PubMed]

206. Boncompain, G.; Perez, F. The many routes of Golgi-dependent trafficking. Histochem. Cell Biol. 2013, 140, 251-260. [CrossRef] [PubMed]

207. Van Vliet, C.; Thomas, E.C.; Merino-Trigo, A.; Teasdale, R.D.; Gleeson, P.A. Intracellular sorting and transport of proteins. Prog. Biophys. Mol. Biol. 2003, 83, 1-45. [CrossRef]

208. Cho, J.H.; Saini, D.K.; Karunarathne, W.K.; Kalyanaraman, V.; Gautam, N. Alteration of Golgi structure in senescent cells and its regulation by a G protein gamma subunit. Cell Signal. 2011, 23, 785-793. [CrossRef]

209. Jiang, Q.; Wang, L.; Guan, Y.; Xu, H.; Niu, Y.; Han, L.; Wei, Y.P.; Lin, L.; Chu, J.; Wang, Q.; et al. Golgin-84-associated Golgi fragmentation triggers tau hyperphosphorylation by activation of cyclin-dependent kinase-5 and extracellular signal-regulated kinase. Neurobiol. Aging 2014, 35, 1352-1363. [CrossRef]

210. Udono, M.; Fujii, K.; Harada, G.; Tsuzuki, Y.; Kadooka, K.; Zhang, P.; Fujii, H.; Amano, M.; Nishimura, S.; Tashiro, K.; et al. Impaired ATP6V0A2 expression contributes to Golgi dispersion and glycosylation changes in senescent cells. Sci. Rep. 2015, 5, 17342. [CrossRef]

211. Despres, J.; Ramdani, Y.; di Giovanni, M.; Benard, M.; Zahid, A.; Montero-Hadjadje, M.; Yvergnaux, F.; Saguet, T.; Driouich, A.; Follet-Gueye, M.L. Replicative senescence of human dermal fibroblasts affects structural and functional aspects of the Golgi apparatus. Exp. Dermatol. 2019, 28, 922-932. [CrossRef] [PubMed]

212. Jerome, W.G.; Cash, C.; Webber, R.; Horton, R.; Yancey, P.G. Lysosomal lipid accumulation from oxidized low density lipoprotein is correlated with hypertrophy of the Golgi apparatus and trans-Golgi network. J. Lipid Res. 1998, 39, 1362-1371.

213. Gorlach, A.; Klappa, P.; Kietzmann, T. The endoplasmic reticulum: Folding, calcium homeostasis, signaling, and redox control. Antioxid. Redox Signal. 2006, 8, 1391-1418. [CrossRef] [PubMed]

214. Ron, D.; Walter, P. Signal integration in the endoplasmic reticulum unfolded protein response. Nat. Rev. Mol. Cell Biol. 2007, 8, 519-529. [CrossRef]

215. Hetz, C. The unfolded protein response: Controlling cell fate decisions under ER stress and beyond. Nat. Rev. Mol. Cell Biol. 2012, 13, 89-102. [CrossRef]

216. Verfaillie, T.; Salazar, M.; Velasco, G.; Agostinis, P. Linking ER Stress to Autophagy: Potential Implications for Cancer Therapy. Int. J. Cell Biol. 2010, 2010, 930509. [CrossRef] [PubMed]

217. Schroder, M.; Kaufman, R.J. The mammalian unfolded protein response. Annu. Rev. Biochem. 2005, 74, 739-789. [CrossRef] [PubMed]

218. Pluquet, O.; Pourtier, A.; Abbadie, C. The unfolded protein response and cellular senescence. A review in the theme: Cellular mechanisms of endoplasmic reticulum stress signaling in health and disease. Am. J. Physiol. Cell Physiol. 2015, 308, C415-C425. [CrossRef]

219. Druelle, C.; Drullion, C.; Desle, J.; Martin, N.; Saas, L.; Cormenier, J.; Malaquin, N.; Huot, L.; Slomianny, C.; Bouali, F; , et al. ATF6alpha regulates morphological changes associated with senescence in human fibroblasts. Oncotarget 2016, 7, 67699-67715. [CrossRef] 
220. Matos, L.; Gouveia, A.M.; Almeida, H. ER Stress Response in Human Cellular Models of Senescence. J. Gerontol. A Biol. Sci. Med. Sci. 2015, 70, 924-935. [CrossRef]

221. Denoyelle, C.; Abou-Rjaily, G.; Bezrookove, V.; Verhaegen, M.; Johnson, T.M.; Fullen, D.R.; Pointer, J.N.; Gruber, S.B.; Su, L.D.; Nikiforov, M.A.; et al. Anti-oncogenic role of the endoplasmic reticulum differentially activated by mutations in the MAPK pathway. Nat. Cell Biol. 2006, 8, 1053-1063. [CrossRef] [PubMed]

222. Bommiasamy, H.; Back, S.H.; Fagone, P.; Lee, K.; Meshinchi, S.; Vink, E.; Sriburi, R.; Frank, M.; Jackowski, S.; Kaufman, R.J.; et al. ATF6alpha induces XBP1-independent expansion of the endoplasmic reticulum. J. Cell Sci. 2009, 122, 1626-1636. [CrossRef] [PubMed]

223. Sriburi, R.; Bommiasamy, H.; Buldak, G.L.; Robbins, G.R.; Frank, M.; Jackowski, S.; Brewer, J.W. Coordinate regulation of phospholipid biosynthesis and secretory pathway gene expression in XBP-1(S)-induced endoplasmic reticulum biogenesis. J. Biol. Chem. 2007, 282, 7024-7034. [CrossRef]

224. Cormenier, J.; Martin, N.; Desle, J.; Salazar-Cardozo, C.; Pourtier, A.; Abbadie, C.; Pluquet, O. The ATF6alpha arm of the Unfolded Protein Response mediates replicative senescence in human fibroblasts through a COX2/prostaglandin E2 intracrine pathway. Mech. Ageing Dev. 2018, 170, 82-91. [CrossRef]

225. Chen, X.; Guo, X.; Ge, Q.; Zhao, Y.; Mu, H.; Zhang, J. ER Stress Activates the NLRP3 Inflammasome: A Novel Mechanism of Atherosclerosis. Oxid. Med. Cell Longev. 2019, 2019, 3462530. [CrossRef] [PubMed]

226. Civelek, M.; Manduchi, E.; Riley, R.J.; Stoeckert, C.J., Jr.; Davies, P.F. Chronic endoplasmic reticulum stress activates unfolded protein response in arterial endothelium in regions of susceptibility to atherosclerosis. Circ. Res. 2009, 105, 453-461. [CrossRef]

227. Correia-Melo, C.; Jurk, D.; Passos, J.F. Robust multiparametric assessment of cellular senescence. Methods Mol. Biol. 2013, 965, 409-419.

228. Biran, A.; Zada, L.; Abou Karam, P.; Vadai, E.; Roitman, L.; Ovadya, Y.; Porat, Z.; Krizhanovsky, V. Quantitative identification of senescent cells in aging and disease. Aging Cell 2017, 16, 661-671. [CrossRef]

229. Campisi, J.; d'Adda di Fagagna, F. Cellular senescence: When bad things happen to good cells. Nat. Rev. Mol. Cell Biol. 2007, 8, 729-740. [CrossRef]

230. Lawless, C.; Wang, C.; Jurk, D.; Merz, A.; Zglinicki, T.; Passos, J.F. Quantitative assessment of markers for cell senescence. Exp. Gerontol. 2010, 45, 772-778. [CrossRef]

231. Noren Hooten, N.; Evans, M.K. Techniques to Induce and Quantify Cellular Senescence. J. Vis. Exp. 2017, 123, 55533. [CrossRef]

232. Gao, S.G.; Zeng, C.; Li, L.J.; Luo, W.; Zhang, F.J.; Tian, J.; Cheng, C.; Tu, M.; Xiong, Y.L.; Jiang, W.; et al. Correlation between senescence-associated beta-galactosidase expression in articular cartilage and disease severity of patients with knee osteoarthritis. Int. J. Rheum. Dis. 2016, 19, 226-232. [CrossRef]

233. Iwasa, H.; Han, J.; Ishikawa, F. Mitogen-activated protein kinase p38 defines the common senescencesignalling pathway. Genes Cells 2003, 8, 131-144. [CrossRef]

234. Minamino, T.; Komuro, I. Vascular cell senescence: Contribution to atherosclerosis. Circ. Res. 2007, 100, 15-26. [CrossRef]

235. Salama, R.; Sadaie, M.; Hoare, M.; Narita, M. Cellular senescence and its effector programs. Genes Dev. 2014, 28, 99-114. [CrossRef]

236. Swanson, E.C.; Manning, B.; Zhang, H.; Lawrence, J.B. Higher-order unfolding of satellite heterochromatin is a consistent and early event in cell senescence. J. Cell Biol. 2013, 203, 929-942. [CrossRef]

237. Helman, A.; Klochendler, A.; Azazmeh, N.; Gabai, Y.; Horwitz, E.; Anzi, S.; Swisa, A.; Condiotti, R.; Granit, R.Z.; Nevo, Y.; et al. p16(Ink4a)-induced senescence of pancreatic beta cells enhances insulin secretion. Nat. Med. 2016, 22, 412-420. [CrossRef]

238. Coppe, J.P.; Desprez, P.Y.; Krtolica, A.; Campisi, J. The senescence-associated secretory phenotype: The dark side of tumor suppression. Annu. Rev. Pathol. 2010, 5, 99-118. [CrossRef]

239. Prattichizzo, F.; De Nigris, V.; Spiga, R.; Mancuso, E.; La Sala, L.; Antonicelli, R.; Testa, R.; Procopio, A.D.; Olivieri, F.; Ceriello, A. Inflammageing and metaflammation: The yin and yang of type 2 diabetes. Ageing Res. Rev. 2018, 41, 1-17. [CrossRef]

240. Libby, P.; Ridker, P.M.; Hansson, G.K. Inflammation in atherosclerosis: From pathophysiology to practice. J. Am. Coll Cardiol. 2009, 54, 2129-2138. [CrossRef]

241. Ridker, P.M. From C-Reactive Protein to Interleukin-6 to Interleukin-1: Moving Upstream To Identify Novel Targets for Atheroprotection. Circ. Res. 2016, 118, 145-156. [CrossRef] 
242. Passos, J.F.; Saretzki, G.; Ahmed, S.; Nelson, G.; Richter, T.; Peters, H.; Wappler, I.; Birket, M.J.; Harold, G.; Schaeuble, K.; et al. Mitochondrial dysfunction accounts for the stochastic heterogeneity in telomere-dependent senescence. PLoS Biol. 2007, 5, e110. [CrossRef]

243. Young, A.R.; Narita, M.; Ferreira, M.; Kirschner, K.; Sadaie, M.; Darot, J.F.; Tavare, S.; Arakawa, S.; Shimizu, S.; Watt, F.M.; et al. Autophagy mediates the mitotic senescence transition. Genes Dev. 2009, 23, 798-803. [CrossRef]

244. Zhang, Z.; Singh, R.; Aschner, M. Methods for the Detection of Autophagy in Mammalian Cells. Curr. Protoc. Toxicol. 2016, 69, 20.12.1-20.12.26. [CrossRef]

245. Kimura, M.; Stone, R.C.; Hunt, S.C.; Skurnick, J.; Lu, X.; Cao, X.; Harley, C.B.; Aviv, A. Measurement of telomere length by the Southern blot analysis of terminal restriction fragment lengths. Nat. Protoc. 2010, 5 , 1596-1607. [CrossRef] [PubMed]

246. Montpetit, A.J.; Alhareeri, A.A.; Montpetit, M.; Starkweather, A.R.; Elmore, L.W.; Filler, K.; Mohanraj, L.; Burton, C.W.; Menzies, V.S.; Lyon, D.E.; et al. Telomere length: A review of methods for measurement. Nurs. Res. 2014, 63, 289-299. [CrossRef]

247. Kurz, D.J.; Decary, S.; Hong, Y.; Erusalimsky, J.D. Senescence-associated (beta)-galactosidase reflects an increase in lysosomal mass during replicative ageing of human endothelial cells. J. Cell Sci. 2000, 113, 3613-3622.

248. Zhang, Y.; Zhao, L.; Wu, Z.; Chen, X.; Ma, T. Galantamine alleviates senescence of U87 cells induced by beta-amyloid through decreasing ROS production. Neurosci. Lett. 2017, 653, 183-188. [CrossRef]

249. Seo, Y.H.; Jung, H.J.; Shin, H.T.; Kim, Y.M.; Yim, H.; Chung, H.Y.; Lim, I.K.; Yoon, G. Enhanced glycogenesis is involved in cellular senescence via GSK3/GS modulation. Aging Cell 2008, 7, 894-907. [CrossRef]

250. Moore, S.A.; Peterson, R.G.; Felten, D.L.; O'Connor, B.L. Glycogen accumulation in tibial nerves of experimentally diabetic and aging control rats. J. Neurol. Sci. 1981, 52, 289-303. [CrossRef]

251. Gertz, H.J.; Cervos-Navarro, J.; Frydl, V.; Schultz, F. Glycogen accumulation of the aging human brain. Mech. Ageing Dev. 1985, 31, 25-35. [CrossRef]

252. St Sauver, J.L.; Boyd, C.M.; Grossardt, B.R.; Bobo, W.V.; Finney Rutten, L.J.; Roger, V.L.; Ebbert, J.O.; Therneau, T.M.; Yawn, B.P.; Rocca, W.A. Risk of developing multimorbidity across all ages in an historical cohort study: Differences by sex and ethnicity. BMJ Open 2015, 5, e006413. [CrossRef]

253. Kirkland, J.L.; Tchkonia, T. Cellular Senescence: A Translational Perspective. EBioMedicine 2017, 21, 21-28. [CrossRef] [PubMed]

254. Hamczyk, M.R.; Villa-Bellosta, R.; Gonzalo, P.; Andres-Manzano, M.J.; Nogales, P.; Bentzon, J.F.; Lopez-Otin, C.; Andres, V. Vascular Smooth Muscle-Specific Progerin Expression Accelerates Atherosclerosis and Death in a Mouse Model of Hutchinson-Gilford Progeria Syndrome. Circulation 2018, 138, $266-282$. [CrossRef]

255. Capell, B.C.; Collins, F.S.; Nabel, E.G. Mechanisms of cardiovascular disease in accelerated aging syndromes. Circ. Res. 2007, 101, 13-26. [CrossRef] [PubMed]

256. Wang, J.C.; Bennett, M. Aging and atherosclerosis: Mechanisms, functional consequences, and potential therapeutics for cellular senescence. Circ. Res. 2012, 111, 245-259. [CrossRef]

257. Zhu, Y.; Tchkonia, T.; Pirtskhalava, T.; Gower, A.C.; Ding, H.; Giorgadze, N.; Palmer, A.K.; Ikeno, Y.; Hubbard, G.B.; Lenburg, M.; et al. The Achilles' heel of senescent cells: From transcriptome to senolytic drugs. Aging Cell 2015, 14, 644-658. [CrossRef]

258. Xu, M.; Pirtskhalava, T.; Farr, J.N.; Weigand, B.M.; Palmer, A.K.; Weivoda, M.M.; Inman, C.L.; Ogrodnik, M.B.; Hachfeld, C.M.; Fraser, D.G.; et al. Senolytics improve physical function and increase lifespan in old age. Nat. Med. 2018, 24, 1246-1256. [CrossRef]

259. Walaszczyk, A.; Dookun, E.; Redgrave, R.; Tual-Chalot, S.; Victorelli, S.; Spyridopoulos, I.; Owens, A.; Arthur, H.M.; Passos, J.F.; Richardson, G.D. Pharmacological clearance of senescent cells improves survival and recovery in aged mice following acute myocardial infarction. Aging Cell 2019, 18, e12945. [CrossRef]

260. Kirkland, J.L.; Tchkonia, T.; Zhu, Y.; Niedernhofer, L.J.; Robbins, P.D. The Clinical Potential of Senolytic Drugs. J. Am. Geriatr. Soc. 2017, 65, 2297-2301. [CrossRef]

261. Guerrero, A.; Herranz, N.; Sun, B.; Wagner, V.; Gallage, S.; Guiho, R.; Wolter, K.; Pombo, J.; Irvine, E.E.; Innes, A.J.; et al. Cardiac glycosides are broad-spectrum senolytics. Nat. Metab. 2019, 1, 1074-1088. [CrossRef] [PubMed] 
262. Triana-Martínez, F.; Picallos-Rabina, P.; Da Silva-Álvarez, S.; Pietrocola, F.; Llanos, S.; Rodilla, V.; Soprano, E.; Pedrosa, P.; Ferreirós, A.; Barradas, M.; et al. Identification and characterization of Cardiac Glycosides as senolytic compounds. Nat. Commun. 2019, 10, 4731. [CrossRef]

263. Fuhrmann-Stroissnigg, H.; Ling, Y.Y.; Zhao, J.; McGowan, S.J.; Zhu, Y.; Brooks, R.W.; Grassi, D.; Gregg, S.Q.; Stripay, J.L.; Dorronsoro, A.; et al. Identification of HSP90 inhibitors as a novel class of senolytics. Nat. Commun. 2017, 8, 422. [CrossRef] [PubMed]

264. Lazaro, I.; Oguiza, A.; Recio, C.; Mallavia, B.; Madrigal-Matute, J.; Blanco, J.; Egido, J.; Martin-Ventura, J.L.; Gomez-Guerrero, C. Targeting HSP90 Ameliorates Nephropathy and Atherosclerosis Through Suppression of NF-KB and STAT Signaling Pathways in Diabetic Mice. Diabetes 2015, 64, 3600-3613. [CrossRef] [PubMed]

265. Stojanović, S.D.; Fiedler, J.; Bauersachs, J.; Thum, T.; Sedding, D.G. Senescence-induced inflammation: An important player and key therapeutic target in atherosclerosis. Eur. Heart J. 2020, 41, 2983-2996. [CrossRef] [PubMed]

266. Mattison, J.A.; Wang, M.; Bernier, M.; Zhang, J.; Park, S.S.; Maudsley, S.; An, S.S.; Santhanam, L.; Martin, B.; Faulkner, S.; et al. Resveratrol prevents high fat/sucrose diet-induced central arterial wall inflammation and stiffening in nonhuman primates. Cell Metab. 2014, 20, 183-190. [CrossRef] [PubMed]

267. Gao, D.; Zuo, Z.; Tian, J.; Ali, Q.; Lin, Y.; Lei, H.; Sun, Z. Activation of SIRT1 Attenuates Klotho Deficiency-Induced Arterial Stiffness and Hypertension by Enhancing AMP-Activated Protein Kinase Activity. Hypertension 2016, 68, 1191-1199. [CrossRef]

268. Chen, H.Z.; Wang, F.; Gao, P.; Pei, J.F.; Liu, Y.; Xu, T.T.; Tang, X.; Fu, W.Y.; Lu, J.; Yan, Y.F.; et al. Age-Associated Sirtuin 1 Reduction in Vascular Smooth Muscle Links Vascular Senescence and Inflammation to Abdominal Aortic Aneurysm. Circ. Res. 2016, 119, 1076-1088. [CrossRef]

269. Liu, Y.; Wang, T.T.; Zhang, R.; Fu, W.Y.; Wang, X.; Wang, F.; Gao, P.; Ding, Y.N.; Xie, Y.; Hao, D.L.; et al. Calorie restriction protects against experimental abdominal aortic aneurysms in mice. J. Exp. Med. 2016, 213, 2473-2488. [CrossRef]

270. van der Veer, E.; Ho, C.; O’Neil, C.; Barbosa, N.; Scott, R.; Cregan, S.P.; Pickering, J.G. Extension of human cell lifespan by nicotinamide phosphoribosyltransferase. J. Biol. Chem. 2007, 282, 10841-10845. [CrossRef]

271. Imai, S.; Guarente, L. NAD+ and sirtuins in aging and disease. Trends Cell Biol. 2014, 24, 464-471. [CrossRef]

272. Werner, C.; Gensch, C.; Poss, J.; Haendeler, J.; Bohm, M.; Laufs, U. Pioglitazone activates aortic telomerase and prevents stress-induced endothelial apoptosis. Atherosclerosis 2011, 216, 23-34. [CrossRef]

273. Huffman, D.M.; Justice, J.N.; Stout, M.B.; Kirkland, J.L.; Barzilai, N.; Austad, S.N. Evaluating Health Span in Preclinical Models of Aging and Disease: Guidelines, Challenges, and Opportunities for Geroscience. J. Gerontol. A Biol. Sci. Med. Sci. 2016, 71, 1395-1406. [CrossRef] [PubMed]

274. Wilkinson, J.E.; Burmeister, L.; Brooks, S.V.; Chan, C.C.; Friedline, S.; Harrison, D.E.; Hejtmancik, J.F.; Nadon, N.; Strong, R.; Wood, L.K.; et al. Rapamycin slows aging in mice. Aging Cell 2012, 11, 675-682. [CrossRef] [PubMed]

275. Zhang, Y.; Bokov, A.; Gelfond, J.; Soto, V.; Ikeno, Y.; Hubbard, G.; Diaz, V.; Sloane, L.; Maslin, K.; Treaster, S.; et al. Rapamycin extends life and health in C57BL/6 mice. J. Gerontol. A Biol. Sci. Med. Sci. 2014, 69, 119-130. [CrossRef] [PubMed]

276. Chapman, J.; Fielder, E.; Passos, J.F. Mitochondrial dysfunction and cell senescence: Deciphering a complex relationship. FEBS Lett. 2019, 593, 1566-1579. [CrossRef]

277. Lesniewski, L.A.; Seals, D.R.; Walker, A.E.; Henson, G.D.; Blimline, M.W.; Trott, D.W.; Bosshardt, G.C.; LaRocca, T.J.; Lawson, B.R.; Zigler, M.C.; et al. Dietary rapamycin supplementation reverses age-related vascular dysfunction and oxidative stress, while modulating nutrient-sensing, cell cycle, and senescence pathways. Aging Cell 2017, 16, 17-26. [CrossRef] [PubMed]

278. Bennaceur, K.; Atwill, M.; Al Zhrany, N.; Hoffmann, J.; Keavney, B.; Breault, D.; Richardson, G.; von Zglinicki, T.; Saretzki, G.; Spyridopoulos, I. Atorvastatin induces T cell proliferation by a telomerase reverse transcriptase (TERT) mediated mechanism. Atherosclerosis 2014, 236, 312-320. [CrossRef]

279. Nasri, H.; Baradaran, A.; Shirzad, H.; Rafieian-Kopaei, M. New concepts in nutraceuticals as alternative for pharmaceuticals. Int. J. Prev. Med. 2014, 5, 1487-1499.

280. Gurău, F.; Baldoni, S.; Prattichizzo, F.; Espinosa, E.; Amenta, F.; Procopio, A.D.; Albertini, M.C.; Bonafè, M.; Olivieri, F. Anti-senescence compounds: A potential nutraceutical approach to healthy aging. Ageing Res. Rev. 2018, 46, 14-31. [CrossRef] 
281. Wang, D.; Zhang, H.; Liang, J.; Li, X.; Feng, X.; Wang, H.; Hua, B.; Liu, B.; Lu, L.; Gilkeson, G.S.; et al. Allogeneic mesenchymal stem cell transplantation in severe and refractory systemic lupus erythematosus: 4 years of experience. Cell Transplant. 2013, 22, 2267-2277. [CrossRef] [PubMed]

282. Bartunek, J.; Behfar, A.; Dolatabadi, D.; Vanderheyden, M.; Ostojic, M.; Dens, J.; El Nakadi, B.; Banovic, M.; Beleslin, B.; Vrolix, M.; et al. Cardiopoietic stem cell therapy in heart failure: The C-CURE (Cardiopoietic stem Cell therapy in heart failURE) multicenter randomized trial with lineage-specified biologics. J. Am. Coll. Cardiol. 2013, 61, 2329-2338. [CrossRef] [PubMed]

(C) 2020 by the authors. Licensee MDPI, Basel, Switzerland. This article is an open access article distributed under the terms and conditions of the Creative Commons Attribution (CC BY) license (http://creativecommons.org/licenses/by/4.0/). 